\title{
Article \\ A High Step-Up Switched Z-Source Converter (HS-SZC) with Minimal Components Count for Enhancing Voltage Gain
}

\author{
Rahul Kumar ${ }^{1}\left(\mathbb{D}\right.$, Ramani Kannan ${ }^{1, *} \mathbb{C}$, Nursyarizal Bin Mohd Nor $^{1}$ and Apel Mahmud ${ }^{2} \mathbb{C}$ \\ 1 Department of Electrical and Electronics Engineering, Universiti Teknologi PETRONAS, \\ Seri Iskandar 32610, Malaysia; rahul_18003246@utp.edu.my (R.K.); \\ nursyarizal_mnor@utp.edu.my (N.B.M.N.) \\ 2 School of Engineering, Deakin University, Melbourne, VIC 3217, Australia; apel.mahmud@deakin.edu.au \\ * Correspondence: ramani.kannan@utp.edu.my
}

check for updates

Citation: Kumar, R.; Kannan, R.; Nor, N.B.M.; Mahmud, A. A High Step-Up Switched Z-Source Converter (HS-SZC) with Minimal Components Count for Enhancing Voltage Gain. Electronics 2021, 10, 924. https:// doi.org/10.3390/electronics10080924

Academic Editor: Bor-Ren Lin

Received: 19 February 2021

Accepted: 23 March 2021

Published: 13 April 2021

Publisher's Note: MDPI stays neutral with regard to jurisdictional claims in published maps and institutional affiliations.

Copyright: (c) 2021 by the authors. Licensee MDPI, Basel, Switzerland. This article is an open access article distributed under the terms and conditions of the Creative Commons Attribution (CC BY) license (https:// creativecommons.org/licenses/by/ $4.0 /)$.

\begin{abstract}
Some applications such as fuel cells or photovoltaic panels offer low output voltage, and it is essential to boost this voltage before connecting to the grid through an inverter. The Z-network converter can be used for the DC-DC conversion to enhance the output voltage of renewable energy sources. However, boosting capabilities of traditional Z-network boost converters are limited, and the utilization of higher parts count makes it bulky and expensive. In this paper, an efficient, high step-up, switched Z-source DC-DC boost converter (HS-SZC) is presented, which offers a higher boost factor at a smaller duty ratio and avoids the instability due to the saturation of inductors. In the proposed converter, the higher voltage gain is achieved by using one inductor and switch at the back end of the conventional Z-source DC-DC converter (ZSC). The idea is to utilize the output capacitor for filtering and charging and discharging loops. Moreover, the proposed converter offers a wider range of load capacity, thus minimizing the power losses and enhancing efficiency. This study simplifies the structure of conventional Z-source converters through the deployment of fewer components, and hence making it more cost-effective and highly efficient, compared to other DC-DC boost converters. Furthermore, a comparison based on the boosting capability and number of components is provided, and the performance of the proposed design is analyzed with non-ideal elements. Finally, simulation and experimental studies are carried out to evaluate and validate the performance of the proposed converter.
\end{abstract}

Keywords: DC-DC converter; switched Z-source; high voltage gain; renewable energy sources; low voltage

\section{Introduction}

Renewable energy sources (RESs) are considered as alternatives to conventional fossil fuel-based power generation systems due to several benefits. The solar photovoltaic (PV) system is considered one of the most popular RESs, while hydrogen fuel cells (FCs) are gaining popularity. However, the output voltage generated by both PV units or FCs is lower than the desired voltage level for the integration with the main grid through voltage source inverters [1,2]. One solution for achieving the desired voltage level is to use multiple PV cells or FCs in series in which several cells might be shaded and become reverse biased, i.e., working as a load rather than a source. Furthermore, the power mismatch in PV or FC modules can lead to high power dissipation; hence, the output power decreases [3-5]. Therefore, DC-DC boost converters are required to achieve the desired voltage gain so that the voltage level can be increased from the lower value to higher. Theoretically, traditional DC-DC converters offer high voltage gain; however, the performance is not promising in practical applications. For example, converters in refs. [6-8] are presented for grid-connected inverter applications. However, the boost factor is lower, which will lead to the utilization of a higher duty cycle; thus, the higher-rated components need to be selected that will increase the cost of the system. Moreover, these converters suffer from large reverse recovery problems [9]. 
Therefore, the configurations of DC-DC converters play a vital role in the effective integration of RESs.

Numerous voltage-boosting techniques are provided in the existing literature. For example, the voltage lift technique is employed in [10], which increases the boost ability; however, it is not suitable for high power applications. The DC-DC converter in [11] utilizes coupled inductors to enhance the boost capability nevertheless the stress on switches increases due to voltage spikes with a larger amplitude. In ref. [12], switched capacitorsswitched inductor cells are used in DC-DC converters to obtain a higher voltage gain. However, the cost of the proposed design increased due to utilization of higher part count that makes the circuit complex and bulky. The DC-DC converter with switched inductors technique is presented in [13] to enhance the boost ability; however, it requires more passive components. Similarly, the voltage multiplier technique is reported in [14] to enhance the voltage gain though it requires several cells with higher ratings. Since all these techniques for DC-DC converters are complex and increase the cost and size of the system, a completely new topology is required to solve these problems.

A simple and efficient idea is presented in [15] by proposing a Z-source topology, as shown in Figure 1.

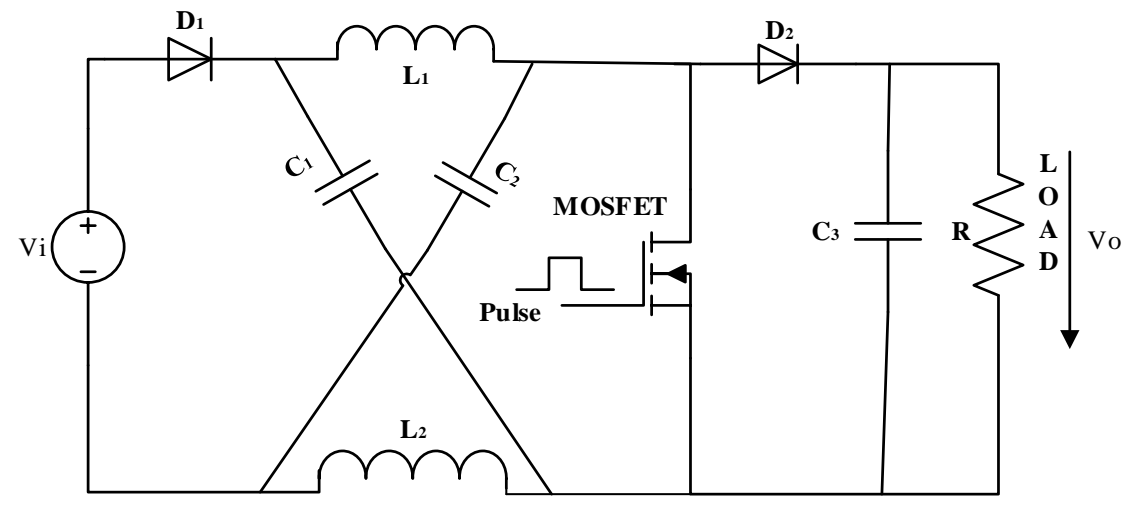

Figure 1. The traditional Z-source DC-DC converter (ZSC) [5].

The Z-source network in Figure 1 comprises two inductors and capacitors connected in $X$ shape through which the problems of shoot-through and limited voltage gain in traditional voltage DC-DC converters can be resolved to some extent. However, the DCDC converter with the Z-source network in [15] suffers from the limitation of the lower range of the boost ratio. Recent studies demonstrate that conventional Z-source converters also suffer from few drawbacks, e.g., the high voltage stress on capacitors, discrete input current, large inrush starting current, extreme duty cycle utilization for the high voltage gain, etc. Moreover, it does not provide a common ground for the input and output that results in the higher cost, increased complexity, and larger voltage stress on semiconductor devices [16,17].

Several enhancements are made to Z-source converters in order to solve the problems associated with classical converters in a similar frame. For example, switched inductorcapacitor technology is used in $[18,19]$ to design the Z-source converter. However, the problem still persists as it exhibits a limited voltage gain. Moreover, these topologies have employed a higher number of components that increase the total cost of the system. A high voltage gain is realized in $[20,21]$ by using Z-network based isolated boost converter. Nevertheless, switches experience high voltage spikes due to the coupled inductors in this configuration. In ref. [22], a Z-source DC-DC converter (ZSC) based on the coupled inductor and switched capacitor technique is proposed. The proposed design attains higher gain without utilizing a higher duty cycle. Moreover, the output diode is switched off at zero current, thereby reducing the reverse recovery problem of diodes. However, this design has utilized the higher part count that has made the circuit complex and increased the total cost of the converter. A three-Z-network converter topology is proposed in [23], which has 
the capability to generate the high voltage gain but at the cost of a large number of passive components and high duty cycles. Similarly, the converter topology as presented in [24,25] utilizes voltage multipliers to increase the boost capability of the converter. However, the switch stress is very high due to high passive components, while showing an increasing trend for other factors, e.g., size, weight, and cost of the converter. Although converters provided in [26-28], ensure enhanced gain for the smaller duty cycle, the limitations of high passive components still exist in these converters.

This paper presents a high step-up, switched Z-source converter (HS-SZC) topology to reduce the number of passive components in a circuit while offering a high boost ratio for the smaller duty cycle. The proposed converter topology with a reduced number of components and high gain can be employed in many practical applications, such as DC microgrids, inverters in the two-stage power conversion system, DC motors, electric vehicles, etc. This converter ensures a wider load capacity, which helps to minimize converter losses by utilizing components with lower power ratings, and thus reducing the cost and size of the converter with enhanced efficiency.

The remainder of this paper is arranged as follows. Section 2 defines the circuit configuration and working principle of the proposed HS-SZC. Calculations of the current and voltage stresses on components are defined in Section 3. Section 4 analyzes the components design principle. Section 5 illustrates the impact of non-ideal elements, and the conditions for the continuous conduction mode (CCM) operation are provided in Section 6. The comparison with conventional Z-network converters is presented in Section 7. Finally, simulation and experimental results are discussed in Sections 8 and 9, respectively, to verify theoretical analysis, while conclusions are drawn in Section 10.

\section{Circuit Configuration and Operating Principle of the Proposed HS-SZC}

This section illustrates the physical structure and steady-state operational principle of the proposed switched Z-source DC-DC converter.

\subsection{The Configuration of the Proposed HS-SZC}

The circuit diagram of the proposed converter is demonstrated in Figure 2, from which it can be observed that it has a very simple structure.

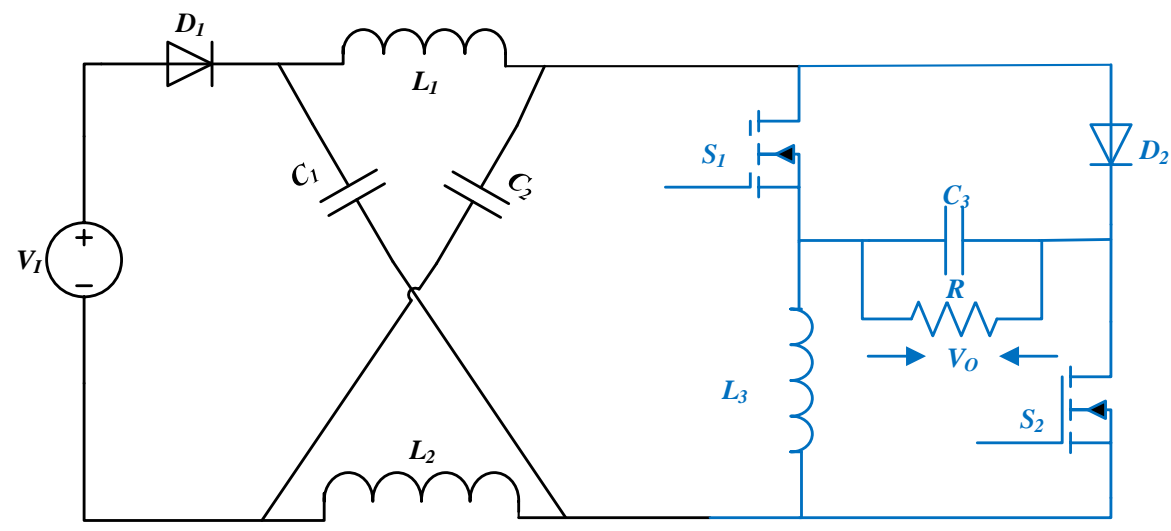

Figure 2. Configuration of the proposed high step-up, switched Z-source DC-DC boost converter (HS-SZC).

The structure in Figure 2 comprises a Z-source network $\left(L_{1}, C_{1}, L_{2}\right.$, and $\left.C_{2}\right)$, two diodes $\left(D_{1}\right.$ and $\left.D_{2}\right)$, two switches $\left(S_{1}\right.$ and $\left.S_{2}\right)$, an inductor $\left(L_{3}\right)$, a filter capacitor $\left(C_{3}\right)$, and load resistance $(R)$. Similar to the conventional Z-network converter in Figure 1 , the proposed design is composed of an extra switch and inductor $\left(L_{3}\right)$ at the backend. The idea is to utilize the output capacitor $\left(C_{3}\right)$ and inductor $\left(L_{3}\right)$ for filtering and charging and discharging loops so that this helps to increase the voltage gain, which is proved in the following subsection. 


\subsection{Operating Principle of the HS-SZC}

This section outlines the steady-state operating principle for the proposed Z-source DCDC converter, as shown in Figure 2. The following assumptions are made for the analysis:

1. Power components are assumed as ideal without having turn-on resistances and voltage drops;

2. Large capacitors are used in order to ignore voltage ripples;

3. The proposed converter is operating in the CCM.

Two switches $S_{1}$ and $S_{2}$ within the proposed converter topology are simultaneously turned OFF and $\mathrm{ON}$ in order to utilize the same gate pulse. Figure 3 shows the switching states of the proposed converter topology. In this topology, capacitors $C_{1}, C_{2}$, and $C_{3}$ discharge energy to inductors $L_{1}, L_{2}$, and $L_{3}$ during the ON state of switches, and hence, the current in inductors $\left(L_{1}, L_{2}\right.$, and $\left.L_{3}\right)$ will be increasing (charging). Similarly, inductors $L_{1}, L_{2}$, and $L_{3}$ release energy to capacitors $C_{1}, C_{2}$, and $C_{3}$, and to loads during the OFF state of switches, and thus, the voltage across capacitors $C_{1}, C_{2}$, and $C_{3}$ will start increasing.

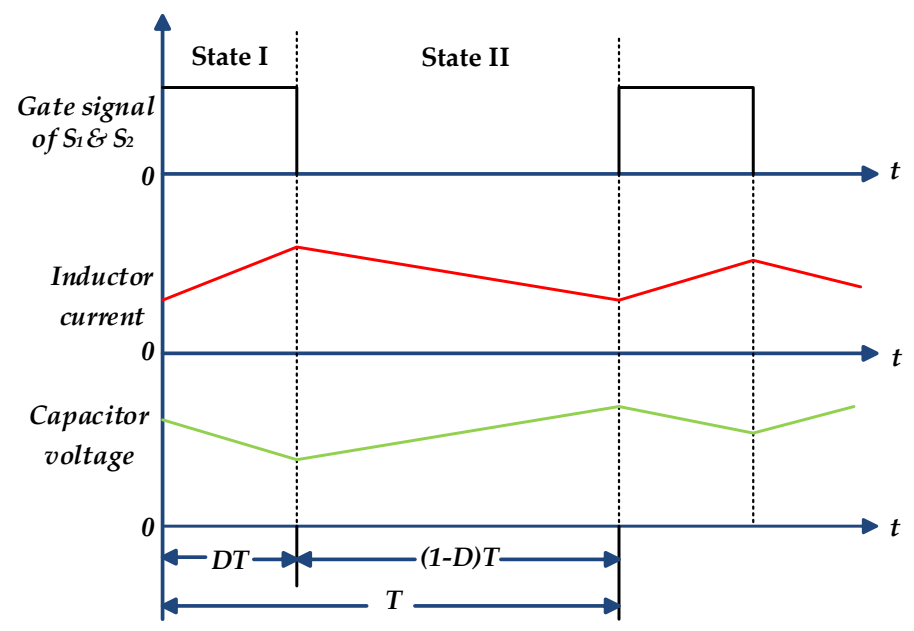

Figure 3. The gating sequence of the HS-SZC.

It is evidenced from Figure 3 that the fundamental operating principle of the proposed HS-SZC is similar to that of a conventional ZSC, in which capacitors discharge energy to inductors in Mode 1 and are charged by inductors and input power supply in Mode 2. [5]. Based on this operating principle, the operational mode of the proposed topology can be classified into two modes, as discussed in the following subsection.

\subsubsection{Mode 1}

The equivalent circuit of the proposed HS-SZC in Mode 1 is shown in Figure 4.

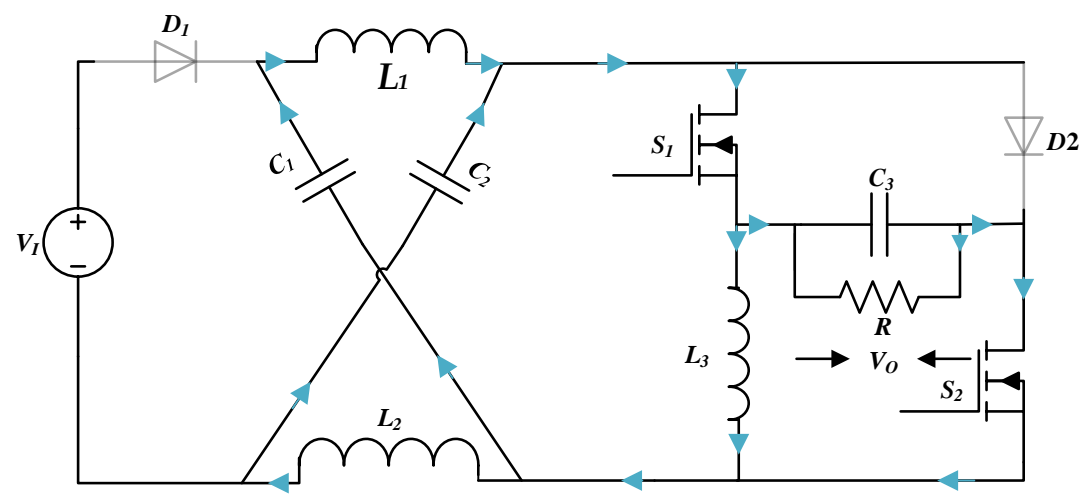

Figure 4. The configuration of the proposed HS-SZC during operating in Mode 1. 
In this mode, both switches will be turned $\mathrm{ON}$ and diodes will be reverse biased. In this condition, $L_{1}$ will be charged by $C_{1}$ and $C_{3} ; L_{2}$ will be charged by $C_{2}$ and $C_{3} ; L_{3}$ will be charged by $C_{2}$ and $C_{3}$; and load will be supplied by the parallel output capacitor $\left(C_{3}\right)$. Referring to the current direction in Figure 4 , the inductor $L_{1}$ has the same current as of the capacitor $C_{1}$ (i.e., $I_{C 1}=I_{L 1}$, where $I_{C 1}$ is the current flowing through $C_{1}$, and $I_{L 1}$ is the current flowing through $L_{1}$ ); the capacitor $C_{2}$ has the equal current as of the inductor $L_{2}$ (i.e., $I_{\mathrm{L} 2}=I_{C 2}$, where $I_{C 2}$ is the current flowing through $C_{2}$, and $I_{L 2}$ is the current flowing through $L_{2}$ ). Similarly, the currents through switch $S_{1}$ and switch $S_{2}$ are the same (i.e., $I_{S 1}=$ $I_{S 2}$, where $I_{S 1}$ is the current flowing through $S_{1}$ and $I_{S 2}$ is the current flowing through $S_{2}$ ). According to Kirchhoff's voltage (KVL) and current laws (KCL), the following equations can be obtained:

$$
\begin{gathered}
V_{L 1}=V_{C 1}+V_{C 3} \\
V_{L 2}=V_{C 2}+V_{C 3} \\
V_{O}=V_{C 3} \\
I_{C 3}=I_{S 1}-I_{O} \\
I_{S 1}=I_{L 1}+I_{L 2}+I_{L 3},
\end{gathered}
$$

where $V_{L 1}$ and $V_{L 2}$ are voltages across $L_{1}$ and $L_{2}$, respectively; $V_{C 1}, V_{C 2}$, and $V_{C 3}$ are voltages across $C_{1}, C_{2}$, and $C_{3}$, respectively; $V_{O}$ is the voltage across the load: $I_{L 3}$ and $I_{C 3}$ are currents through $L_{3}$ and $C_{3}$, respectively; and $I_{O}$ is the current through the load.

\subsubsection{Mode 2}

The equivalent circuit of the proposed HS-SZC operating in Mode 2 is shown in Figure 5 .

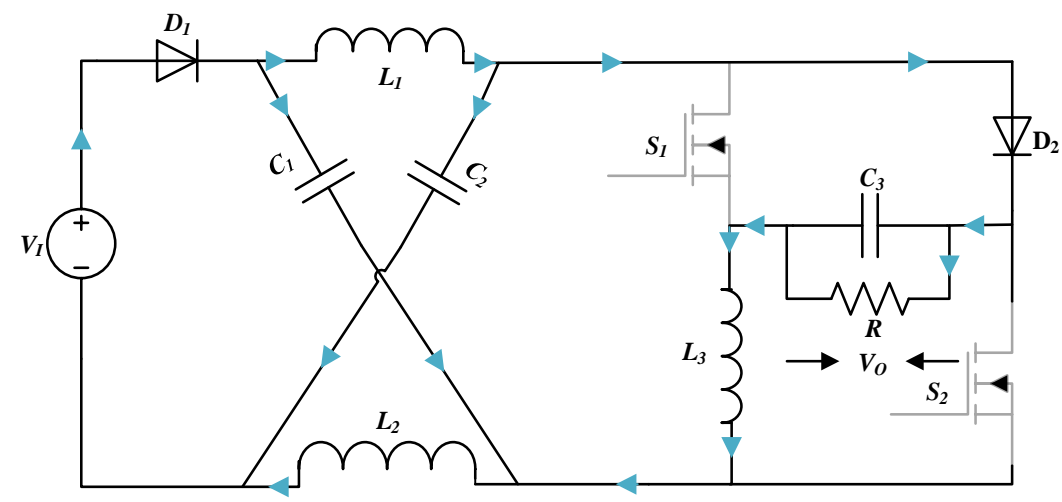

Figure 5. The configuration of the proposed HS-SZC during operating in Mode 2.

In this mode, both switches will be turned OFF and diodes will be forward-biased. Under this condition, the input voltage $\left(V_{I}\right)$ including $L_{1}$ and $L_{2}$ discharge energy to both capacitors $C_{1}$ and $C_{2}$, respectively. Here, $C_{3}$ is charged by all inductors and $V_{I}$, which is also supplied to the load. Referring to the current direction in Figure 5 , diodes $D_{1}$ and $D_{2}$ have the same amount of current. According to Kirchhoff's voltage (KVL) and current laws (KCL), the following equations can be obtained:

$$
\begin{gathered}
V_{L 1}=V_{I}-V_{C 2} \\
V_{L 2}=V_{I}-V_{C 1} \\
V_{L 3}=2 V_{I}-V_{C 1} \\
V_{C 3}=V_{I}-V_{L 1}-V_{L 2}-V_{L 3} \\
V_{C 3}=V_{I}+V_{C 1}
\end{gathered}
$$




$$
\begin{aligned}
& I_{D 1}=I_{L 1}-I_{C 1} \\
& I_{D 2}=I_{L 1}+I_{C 2},
\end{aligned}
$$

where $V_{L 3}$ is the voltages across $L_{3}$. In order to work under steady-state conditions, the inductor needs to follow the volt-sec principle. The volt-sec principle refers to the fact that the sum of volt-seconds applied to an inductor during on and off time must be zero. The volt-sec is defined as $(L \cdot d i=V \cdot d t)$, which states that the change in the current (di) is proportional to the product of voltages (volts) and time (seconds). Using the volt-sec principle for inductors in both states and solving relevant equations, it can be written as

$$
\begin{gathered}
V_{C 1}=V_{C 2}=\frac{2-D}{1-3 D} V_{I} \\
V_{O}=\frac{3-4 D}{1-3 D} V_{I} \\
G=\frac{V_{O}}{V_{I}}=\frac{3-4 D}{1-3 D},
\end{gathered}
$$

where $G$ and $D$ are defined as gain factor and duty cycle, respectively. Apart from these two modes, the proposed converter can go to the transient mode. In this case, switches will experience higher voltage spikes; thus, more power losses will occur. In general, in order to avoid this situation snubber circuits are utilized as discussed in [29]. Moreover, from Equation (15), it is worth noting that the boost ability of the proposed switched converter is $(3-4 D) /(1-3 D)$, which is higher than other converters presented in literature. From Equation (14), it can be observed that the value of $D$ should not exceed 0.33 in order to avoid instability due to the saturation of inductors and singularity problems. The detailed calculations of current stresses on components are discussed in the following section.

\section{Calculation of Current Stresses}

For an ideal condition, the input and output power for the proposed HS-SZC can be specified as

$$
P_{O}=P_{I}
$$

which can be written as

$$
V_{I} I_{I}=V_{O} I_{O}
$$

where $I_{I}$ is the input current. Under this condition, the average input current can be obtained as

$$
I_{I}=\frac{V_{O}}{V_{I}} I_{O}
$$

Since,

$$
\frac{V_{O}}{V_{I}}=\frac{3-4 D}{1-3 D}
$$

therefore,

$$
I_{I}=\frac{3-4 D}{1-3 D} I_{O}
$$

From Figure 2, the input voltage $V_{I}$ has a series connection with diode $D_{1}$, i.e., $\left(I_{I}=I_{D 1}\right)$, where $I_{D 1}$ is the current flowing through $D_{1}$. Therefore, the input current can also be written as

$$
I_{I}=\frac{1}{T} \int_{D T}^{T} I_{D 1} d t
$$

Since, $I_{I}=I_{D 1}$, putting the value of $I_{I}$ in Equation (20), it can be written as

$$
I_{D 1}=\frac{3-4 D}{1-3 D} I_{O}
$$


Further simplifying and considering the current Equations in Mode 2, the following Equation can be obtained:

$$
I_{L 1}=I_{L 2}=\frac{3-4 D}{1-3 D} I_{O}
$$

Using the Equations (1)-(12), the current stress on components can be derived as follows:

The current stress on $D_{1}$ is

$$
I_{D 1}=\frac{3-4 D}{1-3 D} I_{O}
$$

The current stress on $D_{2}$ is

$$
I_{D 2}=\frac{3+8 D^{2}-10 D}{1-3 D} I_{O}
$$

The current stresses on $S_{1}$ and $S_{2}$ are

$$
I_{S 1}=I_{S 2}=\frac{3 D(3-4 D)}{1-3 D} I_{O} .
$$

Table 1 list the voltage and current stress on each component.

Table 1. Current and voltage parameters of the HS-SZC.

\begin{tabular}{cccc}
\hline Parameters & Component Stress & Parameters & Component Stress \\
\hline Output voltage $\left(V_{O}\right)$ & $\frac{3-4 D}{1-3 D} V_{I}$ & Input current $\left(I_{I}\right)$ & $\frac{3-4 D}{1-3 D} I_{O}$ \\
\hline Voltage stresses on capacitors $\left(V_{C 1}\right)$ and $\left(V_{C 2}\right)$ & $\frac{2-D}{1-3 D} V_{I}$ & $\begin{array}{c}\text { Current stresses on } \\
\text { inductors }\left(I_{L 1}\right) \text { and }\left(I_{L 2}\right)\end{array}$ & $\frac{3-4 D}{1-3 D} I_{O}$ \\
\hline Voltage stresses on switches $\left(V_{S 1}\right)$ and $\left(V_{S 2}\right)$ & $\frac{3-4 D}{1-3 D} V_{I}$ & $\begin{array}{c}\text { Current stresses on switches } \\
\left(I_{S 1}\right) \text { and }\left(I_{S 2}\right)\end{array}$ & $\frac{3 D(3-4 D)}{1-3 D} I_{O}$ \\
\hline Current stress on diode $\left(D_{1}\right)$ & $\frac{3-4 D}{1-3 D} I_{O}$ & Current stress on diode $\left(D_{2}\right)$ & $\frac{3+8 D^{2}-10 D}{1-3 D} I_{O}$ \\
\hline
\end{tabular}

\section{Component Design Principle}

The component design is generally dependent on current and voltage stresses, which are provided in Table 1. In this section, the analysis of the component design principle for the proposed HS-SZC is described in detail.

\subsection{Inductor Design}

The following equation can be used to determine the inductor:

$$
V_{L}=L \frac{\Delta I_{L}}{d t} .
$$

By considering the inductor during the operational Mode 1, Equation (27) can be written as

$$
\Delta I_{L}=\frac{1}{L} \int_{0}^{D T} V_{L} d t
$$

It can be further simplified as

$$
\Delta I_{L}=\frac{V_{L} D}{L f_{S}}
$$

Substituting Equation (1) into Equation (29) and further simplifying the equation, it can be obtained as

$$
\Delta I_{L}=\frac{5 D(1-D) V_{I}}{(1-3 D) L f_{S}}
$$


where $\Delta I_{L}$ and $f_{S}$ denote the inductor current ripple and switching frequency, respectively. Subsequently, a larger current ripple will produce higher current stresses on diodes and switches; therefore, this value should be minimized. Normally, the current ripple is described as

$$
\Delta I_{L}=X_{L} \% I_{L},
$$

where $X_{L} \%$ is the percentage inductor current ripple. Using Equation (30) into Equation (31) and assuming $X_{L} \%$ as the maximum current ripple of the inductor in Mode 1, it can be written as

$$
L=\frac{5 D(1-D) V_{I}}{(1-3 D) f_{S} X_{L} \% I_{L}} .
$$

Finally, Equation (32) can be used to determine the inductors $\left(L_{1}, L_{2}\right.$, and $\left.L_{3}\right)$ for the proposed topology.

\subsection{Capacitor Design}

The following equation can be used to determine the capacitor:

$$
I_{C}=\frac{C \Delta V_{C}}{d t} .
$$

By considering the capacitor during the operational in Mode 1, Equation (33) can be written as

$$
\Delta V_{C}=\frac{1}{C} \int_{0}^{D T} I_{C} d t .
$$

That can be further simplified as

$$
\Delta V_{C}=\frac{I_{C} D}{C f_{S}} .
$$

Since the capacitor current $I_{C}$ equals to the inductor current $I_{L}$ during the switch-on period, the substitution of the value of $I_{L}$ into Equation (35) will result in

$$
\Delta V_{C}=\frac{(3-4 D) I_{O} D}{(1-3 D) C f_{S}},
$$

where $\Delta V_{C}$ the capacitor voltage ripple. The larger voltage ripple will reduce the lifetime of the capacitor and it will also require a higher value of the capacitor. Therefore, this value should be minimized for which the capacitor voltage ripple can be described as

$$
\Delta V_{C}=X_{C} \% V_{C},
$$

where $X_{C} \%$ is the percentage capacitor voltage ripple. Using Equation (36) into Equation (37) and assuming Xc\% as the maximum voltage ripple of the capacitor in Mode 1, it can be written as

$$
C=\frac{(3-4 D) I_{O} D}{(2-D) X_{C} \% V_{I} f_{S}} .
$$

Finally, Equation (38) can be used to determine the capacitors $\left(C_{1}, C_{2}\right.$, and $\left.C_{3}\right)$ for the proposed topology.

\subsection{Switch and Diode Design}

The choice of switches and diodes is fully dependent on their voltage and current stresses. For the proposed HS-SZC, the voltage and current stresses are provided in Table 1. It is observed from Table 1 that the voltage stress on the switches is equivalent to the output voltage, whereas the current stress will vary according to the value of the duty cycle. For instance, if $D=0.15$, the current stress will be equivalent to $1.96 I_{O}$. Therefore, the values of output voltage and current must be considered, in order to decide the ratings of switches and diodes. 


\section{Analysis of the Proposed HS-SZC with Non-Ideal Elements}

The impact of parasitic parameters on the proposed converter is studied in this section along with the calculations of the output voltage and efficiency. Parasitic parameters are undesirable circuit elements possessed by electronic components, which are also known as internal parameters. Figures 6 and 7 show the proposed converter with internal parameters and current loops for both operating modes, i.e., for Mode 1 and Mode 2, respectively.

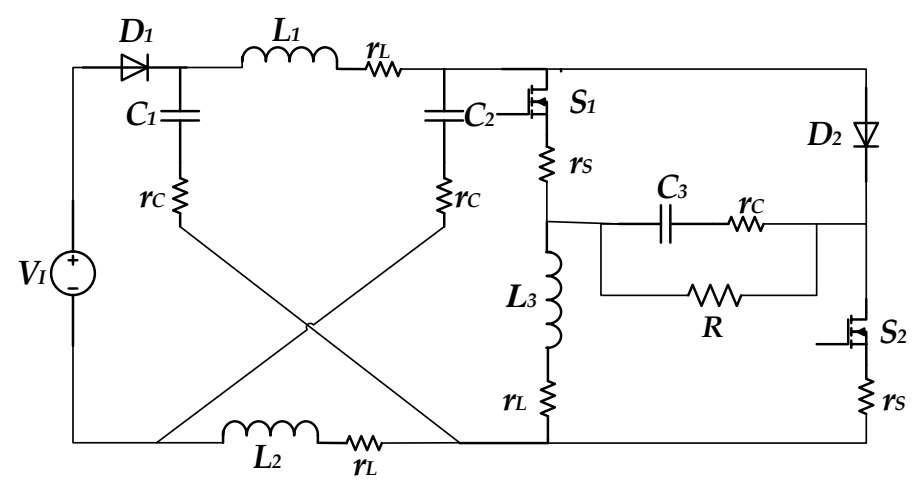

Figure 6. The circuit diagram of the proposed converter with non-ideal elements.

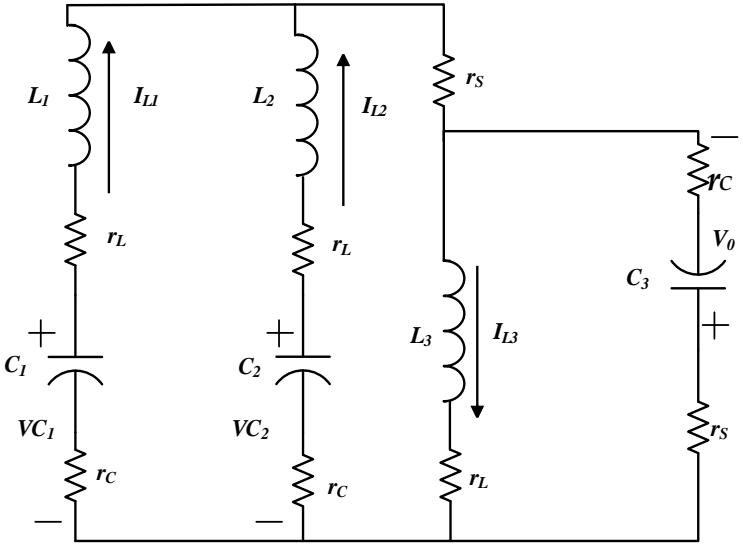

(a)

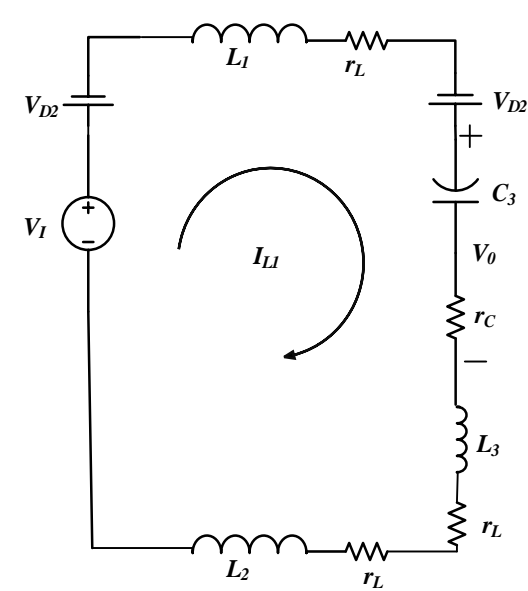

(b)

Figure 7. The equivalent current loops with non-ideal elements: (a) Mode 1 and (b) Mode 2.

Parasitic parameters involve ON resistance $\left(r_{S}\right)$ of both switches, series resistance $\left(r_{C}\right)$ of capacitors, inductor's winding resistance $\left(r_{L}\right)$, and voltage drop for the diode $\left(V_{D}\right)$. It is worth noting that the ripples in the capacitor voltage and inductor current are not considered during the analysis as presented in this section. The impact of these non-ideal elements or parasitic parameters is analyzed based on the output voltage and efficiency, as discussed in the following subsections.

\subsection{Impact of Non-Ideal Elements on the Output Voltage}

The ideal output voltage equation for the proposed converter is given in Equation (13). However, it is essential to analyze the impact of parasitic parameters and the voltage drop across semiconductor devices, which need to be considered during the practical operation, and hence, the actual value of the output voltage will not be the same. Assuming each inductor has an average value of current $I_{L}$, the actual output voltage can be specified as

$$
V_{O}=\frac{(3-4 D) V_{I}-3 I_{L} r_{L}-18 D I_{L} r_{S}(3-4 D)-V_{D}\left(8 D^{2}-14 D+6\right)}{(1-3 D)} .
$$


From Equation (39), it can be observed that the difference between ideal and actual voltage does not depend on the input voltage. The impact of parasitic parameters is analyzed by considering the parameters of the proposed converter, as shown in Table 2.

Table 2. Non-ideal components.

\begin{tabular}{cccccc}
\hline Parameters & Symbol & Value & Parameters & Symbol & Value \\
\hline Duty cycle & $D$ & 0.20 & Inductor resistance & $r_{L}$ & $0-30 \mathrm{~m} \Omega$ \\
Input voltage & $V_{I}$ & $40 \mathrm{~V}$ & Capacitor resistance & $r_{C}$ & $10 \mathrm{~m} \Omega$ \\
Inductor current & $I_{L}$ & $5 \mathrm{~A}$ & Switching frequency & $f_{S}$ & $25 \mathrm{kHz}$ \\
Voltage drop & $V_{D}$ & $0-1.5 \mathrm{~V}$ & Switch resistance & $r_{S}$ & $8.5-14.5 \mathrm{~m} \Omega$ \\
\hline
\end{tabular}

This subsection analyzes the impact of non-ideal elements on the output voltage of the proposed converter by varying the values of $V_{D}$ and $r_{L}$. From this analysis, it can be realized that the proposed converter achieves an ideal gain of more than five times of input voltage $V_{I}$ for the duty cycle, $D=0.20$. However, considering the parasitic parameters in Table 2, this value will be decreased.

Referring to Figure 8, the difference between actual and ideal voltage is that the actual one is inversely proportional to the values of $V_{D}$ and $r_{L}$. Thus, the smaller the values of $V_{D}$ and $r_{L}$, the closer the value of the actual output voltage to the ideal voltage. In a real-world application, switches are not ideal. There are some internal resistances to the power path which directly affects the performance of the converter. Therefore, a higher value of resistance will result in a higher voltage drop, increased power dissipation, and higher power loss. Figure 9 demonstrates the variation of the output voltage with the switch resistance $r_{S}$, in which the lower values of the resistance ensure the higher output voltage. In addition, faster switching is necessary for the converters because it leads to select power components with lower ratings, thus decreasing the cost of the converter. Therefore, these parameters must be kept into consideration for designing simulations and experimental prototypes.

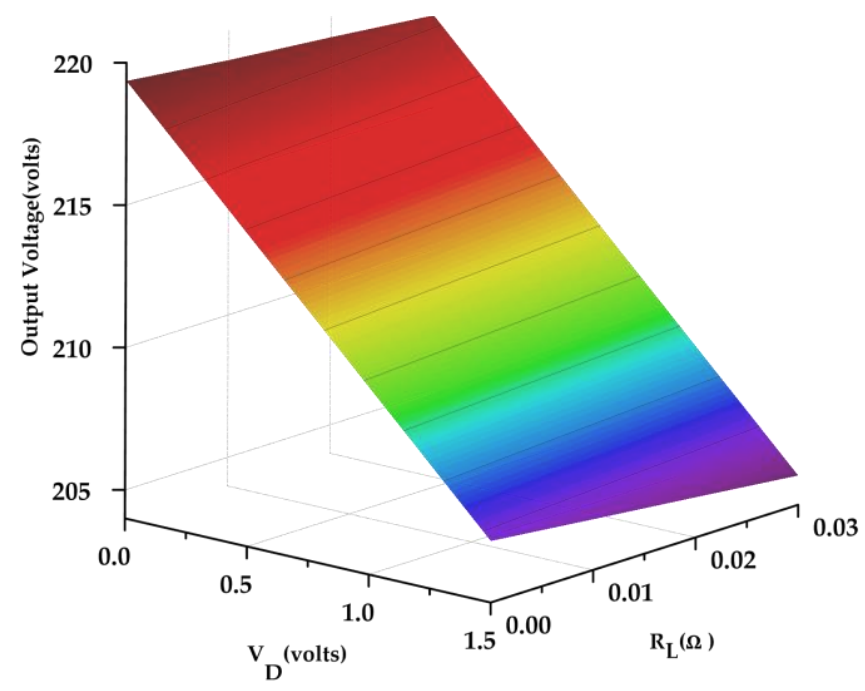

Figure 8. Variation in the theoretical output voltage with changes in $V_{D}$ and $r_{L}$. 


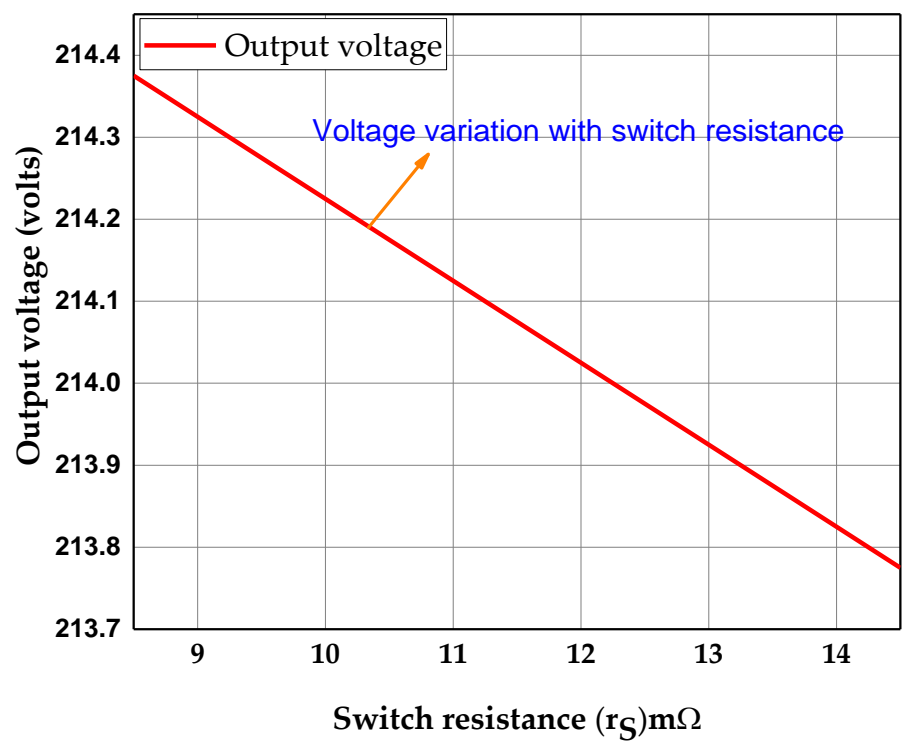

Figure 9. Variation in the theoretical output voltage with changes in $r_{S}$.

\subsection{Impact of Non-Ideal Elements on the Efficiency}

The efficiency calculation for the DC-DC converter is entirely dependent on losses that occur in the converter. The converter losses include conduction and parasitic parameter losses. In this section, to determine the efficiency, the following converter losses are determined for the proposed HS-SZC.

\subsubsection{Power Losses in the Switch}

The power loss in the switch comprises conduction loss and switching loss. The conduction loss depends on the root mean square (r.m.s) value of the switch current and turn-on resistance of switches. However, switching losses occur due to the turn-off and turn-on delay of switches. The conduction loss $\left(P_{C-S W I T C H}\right)$ can be determined by using the following equation:

$$
P_{C-S W I T C H}=I_{r . m . s}^{2} r_{S}
$$

where the r.m.s value of the switch current $\left(I_{r . m . s}\right)$ can be written as

$$
I_{r . m . s}=\sqrt{\frac{1}{T} \int_{0}^{T} I_{S}^{2} d t .}
$$

Furthermore,

$$
\begin{gathered}
I_{S}=\frac{3(3-4 D) I_{O}}{(1-3 D)} \text { for } D<t \leq T . \\
I_{S}=0 \text { for } D T<t \leq T
\end{gathered}
$$

Substituting Equation (42) into Equation (41), it can be written as

$$
I_{r . m . s}=\sqrt{\frac{1}{T}\left(\int_{0}^{D T}\left(\frac{3(3-4 D) I_{O}}{(1-3 D)}\right)^{2} d t+\int_{D T}^{T} 0 d t\right)} .
$$

Substituting Equation (43) into Equation (40), the total conduction loss in the switch can be expressed as

$$
P_{C-S W I T C H}=18 D I_{L}^{2} r_{S} .
$$

Moreover, it can be assumed for switching losses assuming that the linear voltages are applied across the switches and the linear currents flow through switches during turn-on 
and turn-off periods. Thus, switching losses for the proposed switched converter can be specified as $[30,31]$

$$
P_{S}=\frac{2 f_{S} V_{O} I_{L}\left(t_{o n}+t_{o f f}\right)}{3},
$$

where $t_{o n}$ and $t_{o f f}$ indicate turn-on and turn-off times, respectively.

\subsubsection{Power Losses in the Diode}

The diode power loss comprises conduction and reverse recovery losses. The conduction loss depends on the forward voltage drop and the average current flowing through the diode. The conduction loss $\left(P_{C-D I O D E}\right)$ can be determined by using the following equation:

$$
P_{C-D I O D E}=I_{D} V_{F}
$$

where the r.m.s value $\left(I_{D r m s}\right)$ of the diode current $\left(I_{D}\right)$ can be written as

$$
I_{D}=\sqrt{\frac{1}{T} \int_{0}^{T} I_{D} d t}
$$

Furthermore,

$$
\begin{aligned}
& I_{D}=0 \text { for } 0<t \leq D T . \\
& I_{D}=I_{I} \text { for } D T<t \leq T
\end{aligned}
$$

Substituting Equation (48) into Equation (47), it can be written as

$$
I_{D}=\sqrt{\frac{1}{T} \int_{0}^{D T} 0 d t+\int_{D T}^{T}\left(\frac{3-4 D}{1-3 D} I_{O}\right) d t} .
$$

Substituting Equation (49) into Equation (46), total conduction loss in the diode can be expressed as

$$
P_{C-D I O D E}=\frac{2\left((3-4 D) I_{O}\right) V_{D}(1-D)}{1-3 D} .
$$

Furthermore, the diode reverse recovery loss can be estimated as

$$
P_{R R D}=Q_{R R 1} V_{C 1} f_{S}+Q_{R R 2} V_{C 2} f_{S}+Q_{R R 3} V_{C 3} f_{S},
$$

where $Q_{R R 1}, Q_{R R 2}$, and $Q_{R R 3}$ are the reverse recovery charges for $D_{1}, D_{2}$, and $D_{3}$, respectively.

\subsubsection{Power Losses in the Inductor}

The inductor power loss is divided into the core loss and conduction loss (i.e., winding loss). For the pulse width modulator (PWM) converter, core losses are very small and can be avoided, although the conduction loss depends on the rms value of the inductor current $\left(I_{L(r . m . s)}\right)$ and resistance of inductors $r_{L}$. The value of $I_{L(r . m . s)}$ can be expressed as

$$
I_{L(r . m . s)}=\sqrt{\frac{1}{T} \int_{0}^{T} I_{L}^{2} d t .}
$$

Using Equation (52) and doing some simplifications, the total inductor conduction loss $\left(P_{\text {C-INDUCTOR }}\right)$ for the proposed switched converter can be obtained as

$$
P_{C-I N D U C T O R}=3 I_{L}^{2} r_{L} .
$$




\subsubsection{Power Losses in the Capacitor}

The conduction loss in the capacitor depends on the rms value of the capacitor current $\left(I_{C(r . m . s)}\right)$ and value of $r_{C}$, Therefore, for the proposed converter it can be determined by using the following equations:

$$
P_{C-C A P A C I T O R}=I_{C(r . m . s)}^{2}{ }^{r},
$$

where the value of $I_{C(r . m . s)}$ can be written as

$$
I_{C(r . m . s)}=\sqrt{\frac{1}{T} \int_{0}^{T} I_{C}^{2} d t .}
$$

Substituting Equation (55) into Equation (54) and doing some simplifications, the capacitor conduction loss for the proposed switched converter can be obtained as

$$
P_{C-C A P A C I T O R}=(1+5 D) I_{L(r . m . s)}^{2}{ }^{r} \text {. }
$$

5.2.5. Total Power Losses

Generally, the total conduction loss is calculated as

$$
P_{C-T O T A L}=P_{C-S W I T C H}+P_{C-D I O D E}+P_{C-I N D U C T O R}+P_{C-C A P A C I T O R} .
$$

The substitution of Equations (44), (50), (53) and (56) into Equation (57) will result in

$$
P_{C-\text { TOTAL }}=3 I_{L}^{2} r_{L}+(1+5 D) I_{L}^{2} r_{C}+18 D I_{L}^{2} r_{S}+2 V_{D} I_{L}(1-D) .
$$

Based on Equations (45), (51) and (58), the efficiency of the proposed converter can be determined as

$$
\eta=\frac{P_{\text {OUT }}}{P_{I}}=\frac{P_{I}-P_{C-T O T A L}-P_{S}-P_{R R D}}{P_{I}},
$$

where $P_{\text {OUT }}$ and $P_{I}$ are output and input power of the proposed converter, respectively. The impact of non-ideal elements on the efficiency of the proposed converter is analyzed by varying the values of $r_{L}$ and $V_{D}$, including the variation in the switch resistance $\left(r_{S}\right)$. Furthermore, a surface, as shown in Figure 10, has been drawn, adopting the parameters used in Table 2 to determine the effects of non-ideal elements on efficiency.

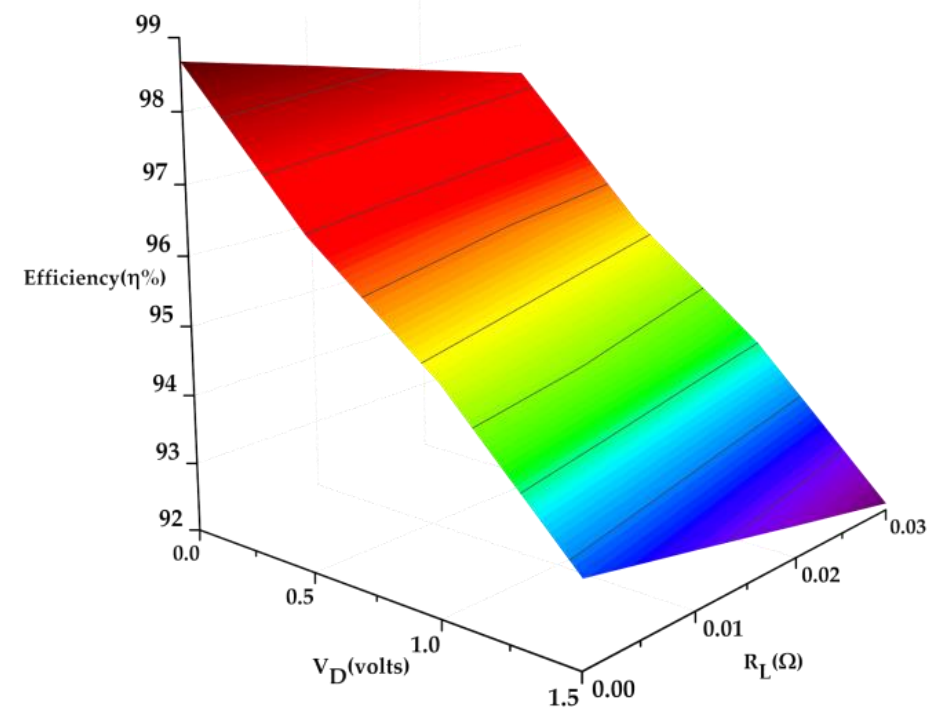

Figure 10. Variation in the theoretical efficiency with changes in $r_{L}$ and $V_{D}$. 
From this analysis, it can be realized that the proposed converter achieves more than $98 \%$ efficiency during an ideal condition. However, considering the parasitic parameters in Table 2, this value will be decreased. Figure 11 also shows the variation in the efficiency with the switch resistance, which indicates that the smaller value of the switch resistance will ensure higher efficiency. Therefore, these parasitic parameters have a significant effect on the efficiency of the converter and there will be higher efficiency of the proposed converter if these values are decreased.

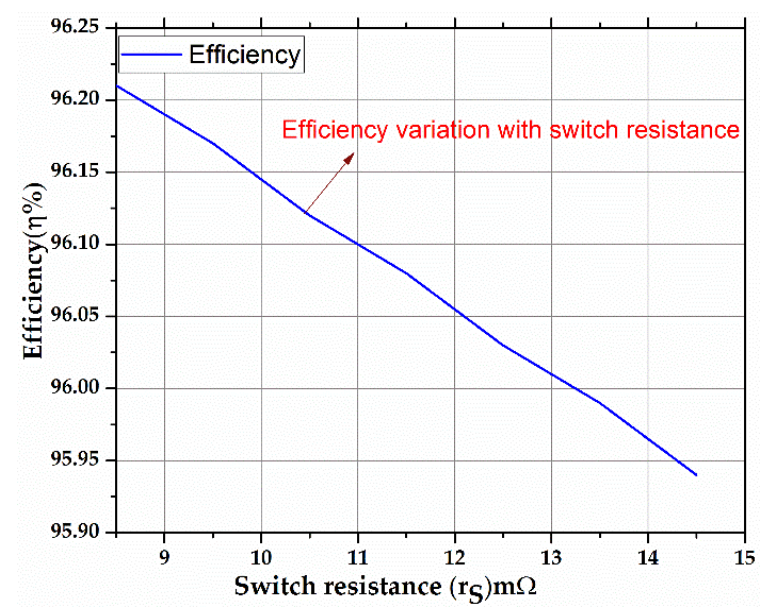

Figure 11. Variation in the theoretical efficiency with changes in $r_{S}$.

\section{Conditions for the CCM Operation and Load Range of the Proposed Converter}

The CCM refers to the value of the inductor current not reaching zero in each state. This section demonstrates the conditions for the CCM operation and compares the load ranges for the proposed switched converter with a conventional Z-source DC-DC converter. For the appropriate CCM operation, the proposed converter must satisfy the following condition:

$$
I_{L}-\frac{\Delta I_{L}}{2} \geq 0
$$

For the switched converter (assuming the input power is equal to output power), it can be written as

$$
P_{I}=P_{O},
$$

which can be written as

$$
V_{I} I_{I}=V_{O} I_{O}
$$

Using the Equations (61) and (62), the inductor current can be written as

$$
I_{L}=\frac{(3-4 D)^{2} V_{I}}{(1-3 D)^{2} R_{L}}
$$

Subsequently, the larger current ripples will generate higher current stresses on diodes and switches.

Using the Equations (60), (63) and (32); the load range in the CCM operation can be written as

$$
R_{L} \leq \frac{2(3-4 D)^{2} L f_{S}}{5 D(1-3 D)(1-D)},
$$

where $R_{L}$ denotes the load resistance. It is clear from Equation (64) that $R_{L}$ is proportional to $L$. Hence, increases in $L$ will enhance the load capacity of the converter. Moreover, the following condition must be satisfied for the CCM operation of the proposed converter:

$$
R_{L} \leq R_{L \max }
$$


where $R_{\text {Lmax }}$ indicates the maximum load at a specific duty cycle. If the above condition is not satisfied the converter will shift to the DCM operation. For comparing the load capacity with the traditional Z-network converter, it can be written as follows [32]:

$$
R_{L} \leq \frac{2 L f_{S}}{(1-2 D)}
$$

It is worth noting that for the purpose of comparison, it is assumed that both converters are working in the CCM for the specified parameters. Moreover, based on Equations (64) and (6), setting $D=0.20$ and $f_{S}=25 \mathrm{kHz}$ the load range of both proposed and traditional converters while working in CCM is shown in Figure 12, from which it can be clearly observed that the proposed converter holds a much wider range, compared to a traditional DC-DC converter having a similar value of the inductor.

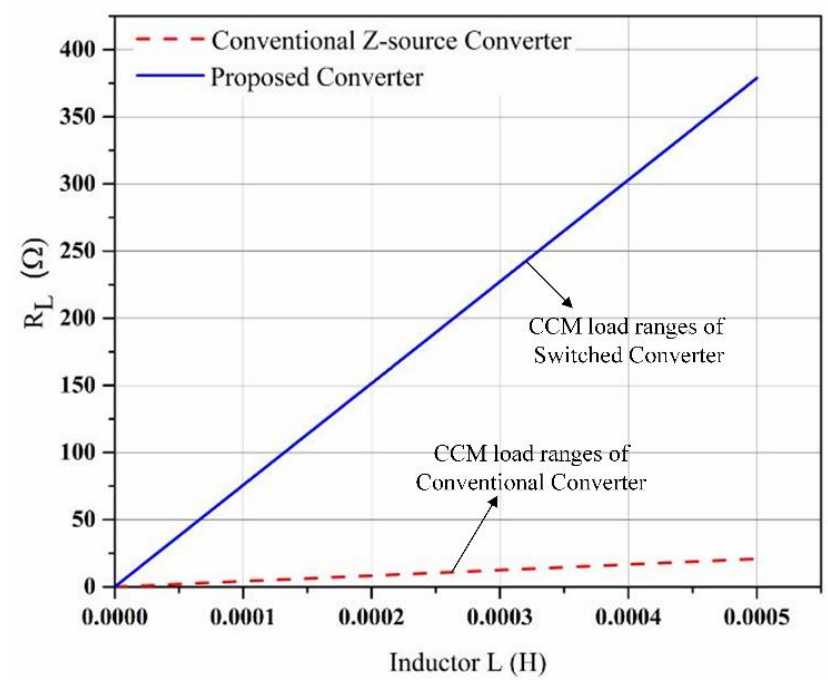

Figure 12. Load range for the proposed converter and traditional Z-source converter.

\section{Comparative Analysis of the Proposed Converter}

In this section, a comprehensive comparison is presented based on the number of components and boost ability in order to highlight the features of the proposed converter, compared to existing converters. Hence, the comparative study is presented in terms of the boost ability and number of components as discussed in the following subsections.

\subsection{Comparison in Terms of the Boost Ability}

As discussed earlier, the boost ability is one of the most significant properties for evaluating the performance of a DC-DC converter. In this subsection, the proposed Z-source converter is compared with other Z-source DC-DC converters presented in [15,26-28] and [33-37]. The voltage gains of converters in [15,26-28] and [33-37] are listed in Table 3.

To demonstrate the boost ability of the proposed converter further, the relationship between the boost factor and duty cycle is shown in Figure 13 from which it can be seen that the proposed converter exhibits higher boost ability as compared to all other Z-source converters in a similar frame. It is worth noting that the range of duty cycle is selected from $0-0.30$ only for the purpose of comparisons. However, the maximum operating duty cycle for the converters in [15,26-28], and is $D<0.5, D<0.5, D<0.33$, and $D<0.33$, respectively; and that of for the converters in [33-37] is $D<1, D<0.5, D<1, D<1$ and $D<1$, respectively. The maximum operating duty cycle for the proposed converter is $D<0.33$. 
Table 3. Performance comparison of the proposed converter and existing converters.

\begin{tabular}{|c|c|c|c|}
\hline Ref. & Components & Gain Factor & Features and Drawbacks \\
\hline [15] & $\begin{array}{l}2 \text { Inductors } \\
3 \text { Capacitors } \\
1 \text { Switch } \\
2 \text { Diodes }\end{array}$ & $\frac{1-D}{1-2 D}$ & $\begin{array}{l}\checkmark \text { Suitable for solving shoot-through problems } \\
\times \text { Low boost factor }\end{array}$ \\
\hline [8] & $\begin{array}{l}3 \text { Inductors } \\
5 \text { Capacitors } \\
1 \text { Switch } \\
3 \text { Diodes }\end{array}$ & $\frac{1}{1-3 D}$ & $\begin{array}{l}\sqrt{ } \text { Utilizing smaller duty cycle for higher gain } \\
\sqrt{ } \text { Higher boost factor } \\
\times \text { The different ground for input and output } \\
\times \text { Utilize a higher number of components }\end{array}$ \\
\hline [9] & $\begin{array}{l}3 \text { Inductors } \\
7 \text { Capacitors } \\
1 \text { Switch } \\
5 \text { Diodes }\end{array}$ & $\frac{2+D}{1-2 D}$ & $\begin{array}{l}\checkmark \text { can attend high gain by adding an extra stage } \\
\sqrt{ } \text { low voltage stresses on components } \\
\times \text { The different ground for input and output } \\
\times \text { Utilize a higher number of components }\end{array}$ \\
\hline [10] & $\begin{array}{l}4 \text { Inductors } \\
3 \text { Capacitors } \\
1 \text { Switch } \\
8 \text { Diodes }\end{array}$ & $\frac{1+D}{1-3 D}$ & $\begin{array}{l}\checkmark \text { Utilizing smaller duty cycle for higher gain } \\
\times \text { Utilize a higher number of components }\end{array}$ \\
\hline [11] & $\begin{array}{l}2 \text { Inductors } \\
6 \text { Capacitors } \\
5 \text { Switches } \\
5 \text { Diodes }\end{array}$ & $\frac{2+D}{1-D}$ & $\begin{array}{l}\checkmark \text { Wide range of voltage gain } \\
\times \text { Utilize a higher number of components }\end{array}$ \\
\hline [12] & $\begin{array}{l}5 \text { Inductors } \\
6 \text { Capacitors } \\
2 \text { Switches } \\
2 \text { Diodes }\end{array}$ & $\frac{1+n(1-D)}{1-2 D}$ & $\begin{array}{l}\checkmark \text { Reduced diode conduction loss } \\
\checkmark \text { common ground between input and output } \\
\times \text { Utilize higher number of components }\end{array}$ \\
\hline [13] & $\begin{array}{l}2 \text { Switches } \\
6 \text { Diodes }(\mathrm{j}=\mathrm{k}=1) \\
2 \text { Inductors } \\
4 \text { Capacitors }\end{array}$ & $\frac{(2 n+1)+D}{1-D}$ & $\begin{array}{l}\checkmark \text { Low voltage stress on components } \\
\checkmark \text { High voltage gain } \\
\times \text { Utilize higher number of components. }\end{array}$ \\
\hline$[36]$ & $\begin{array}{l}1 \text { Switch } \\
4 \text { Diodes } \\
2 \text { Inductors } \\
5 \text { Capacitors }\end{array}$ & $\frac{2+D}{1-D}$ & $\begin{array}{l}\checkmark \text { Increased voltage gain } \\
\times \text { Utilize higher number of components }\end{array}$ \\
\hline$[37]$ & $\begin{array}{l}1 \text { Switch } \\
5 \text { Diodes } \\
1 \text { Inductor } \\
5 \text { Capacitors }\end{array}$ & $\frac{3}{1-D}$ & $\begin{array}{l}\checkmark \text { Low voltage stress on components } \\
\checkmark \text { Common ground } \\
\times \text { Higher parts count. }\end{array}$ \\
\hline Proposed converter & $\begin{array}{l}3 \text { Inductors } \\
3 \text { Capacitors } \\
2 \text { Switches } \\
2 \text { Diodes }\end{array}$ & $\frac{3-4 D}{1-3 D}$ & $\begin{array}{l}\checkmark \text { Utilizing smaller duty cycle for higher gain } \\
\checkmark \text { Higher boost factor } \\
\checkmark \text { Utilize a lower number of components } \\
\checkmark \text { Reduced power loss } \\
\times \text { The different ground for input and output }\end{array}$ \\
\hline
\end{tabular}

\subsection{Comparison in Terms of the Number of Components}

This subsection compares the number of components for the proposed Z-network and other converters presented in [15,26-28] and [34-37]. Table 3 lists the number of components utilized in these converters. The proposed converter utilizes one additional switch and inductor at the backend of the conventional Z-network converter in order to realize a higher boost ratio. From Table 3, it is observed that the proposed converter uses a minimal number of components, compared to other converters, which reduce the cost and size while enhancing the efficiency; the following section presents rigorous simulation and experimental results to analyze the performance of the proposed HS-SZC. 


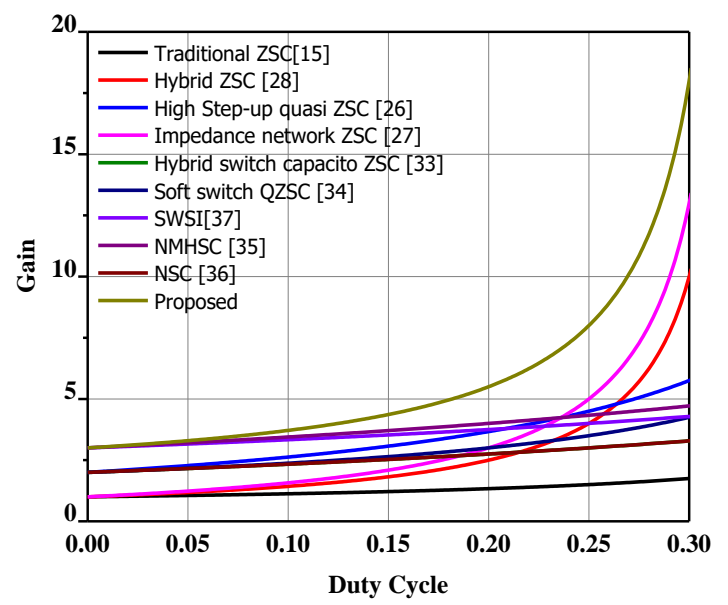

Figure 13. Comparison of the boost ability for the proposed and conventional converters.

\subsection{Comparison in Terms of Voltage Stress}

In this subsection, comparisons are presented based on the voltage across switches for conventional converters in [15,23] and [26-28] against the proposed converter. The comparative results for $\mathrm{V}_{\mathrm{I}}=25 \mathrm{~V}$ are shown in Figure 14. It is worth noting that apart from the converter in [26], the voltage stress across the switch for other converters is equal to the output voltage at a specific duty cycle. For instance, at $\mathrm{D}=0.15$, the value of voltage stress for the proposed converter is $109 \mathrm{~V}$; correspondingly, the value of output voltage for the proposed converter at $\mathrm{D}=0.15$ and $\mathrm{V}_{\mathrm{I}}=25 \mathrm{~V}$ in Figure 13 will be the same. Thus, the proposed converter maintains the features of a traditional ZSC.

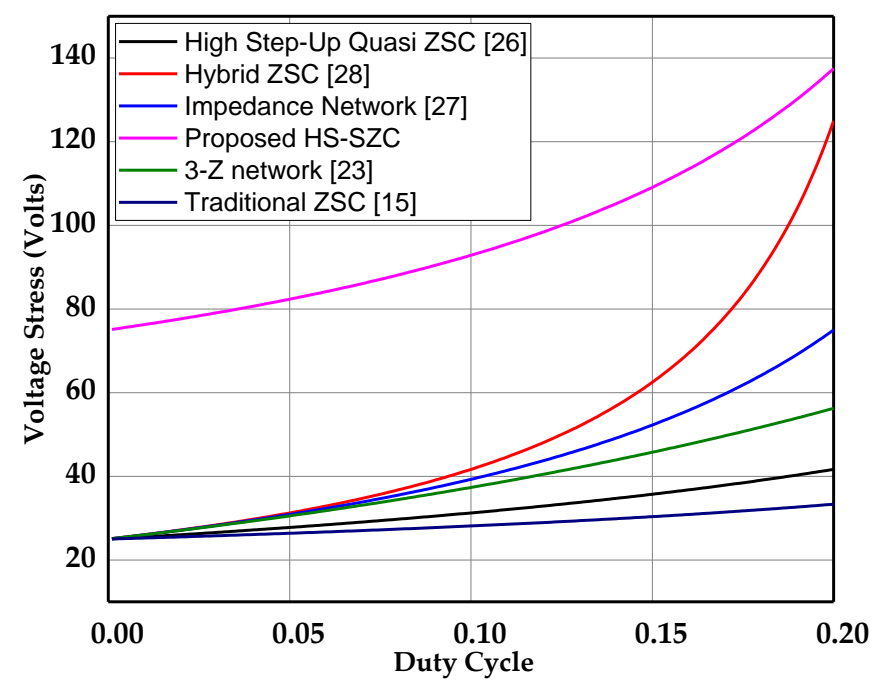

Figure 14. Comparison of the voltage stress for the conventional and proposed converter at the input voltage of $\mathrm{V}_{\mathrm{I}}=25 \mathrm{~V}$.

\section{Simulation Results}

The simulation model for the proposed converter is developed in MATLAB/Simulink environment with specifications of $25 / 107,52 \mathrm{~W}$ to validate the theoretical analysis. The parameters listed in Table 4 are used for simulations. The key waveforms of the simulated converter such as the gate signal, input voltage, output voltage, voltages across switch $S_{1}$ and $S_{2}$, inductor current, and voltages of capacitors $C_{1}$ and $C_{2}$ are manifested in Figures 15 and 16. Figure 15a shows the gate signal for both MOSFETs (Metal Oxide Semiconductor Field Effect Transistors) in which the lower duty ratio $(D=0.15)$ is adopted that minimizes switching losses and enhances the efficiency. Based on Equation (14), the boost factor of the proposed design can be calculated as 4.36 for $D=0.15$. Thus, the simulated values of the input and output voltages in 
Figure $15 \mathrm{~b}$ are $25 \mathrm{~V}$ and $107 \mathrm{~V}$, respectively, which further authenticate the theoretical analysis. As per Equation (13), the theoretical values of voltages across the capacitors $C_{1}$ and $C_{2}$ will be the same and this will be $84 \mathrm{~V}$ for both capacitors and the simulation results in Figure 15c shows this as $82 \mathrm{~V}$. Hence, theoretical and simulation results match with each other. Moreover, Figure 16 shows the simulated value of inductor current and voltages for both MOSFETs and diodes that are $107 \mathrm{~V}$ and $55 \mathrm{~V}$, respectively; hence, simulation results fit with theoretical analysis, which demonstrates the accuracy of the proposed converter.

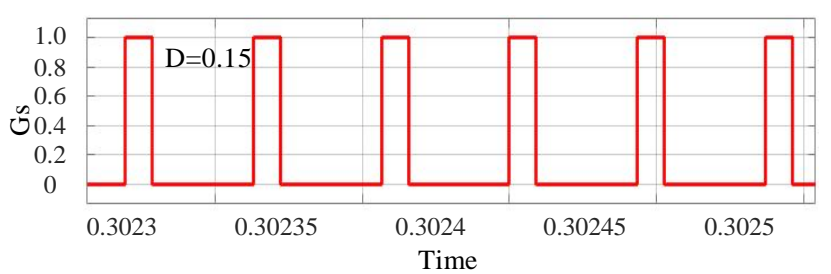

(a)

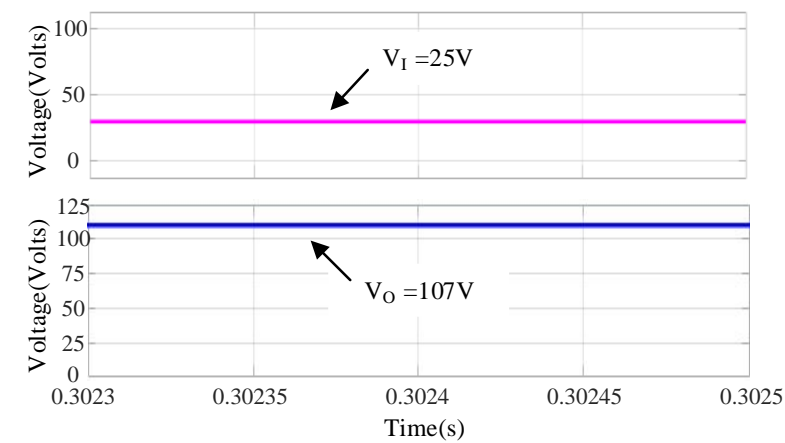

(b)
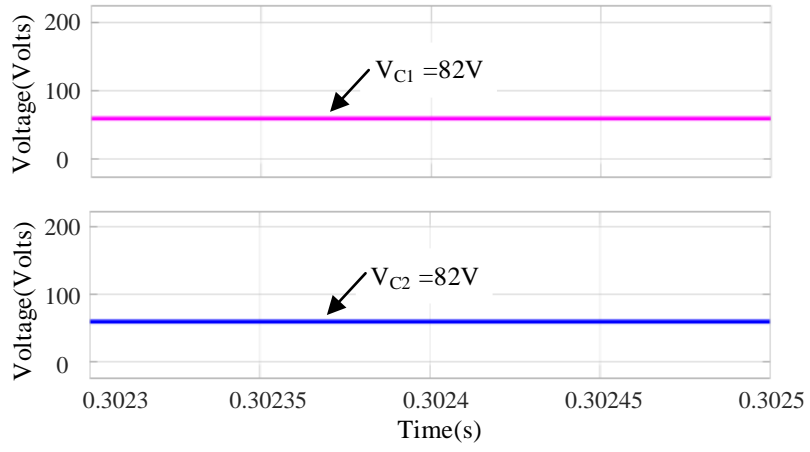

(c)

Figure 15. (a) Gate signals, (b) input and output voltages, and (c) voltages across capacitors $C_{1}$ and $C_{2}$.

Table 4. Simulations and experimental parameters.

\begin{tabular}{cccccc}
\hline Parameters & Symbol & Value & Parameters & Symbol & Value \\
\hline Duty cycle & $D$ & 0.15 & Inductor resistance & $r_{L}$ & $0-30 \mathrm{~m} \Omega$ \\
Input voltage & $V_{I}$ & $25 \mathrm{~V}$ & Capacitor resistance & $r_{C}$ & $10 \mathrm{~m} \Omega$ \\
Inductors & $L_{1-3}$ & $380 \mu \mathrm{H}$ & Switching frequency & $f_{S}$ & $20 \mathrm{kHz}$ \\
Capacitors & $C_{1-3}$ & $330 \mu \mathrm{F}$ & Switch resistance & $r_{S}$ & $12.5 \mathrm{~m} \Omega$ \\
\hline
\end{tabular}




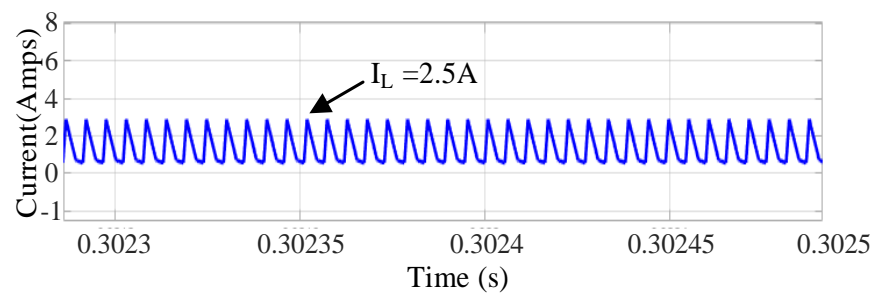

(a)
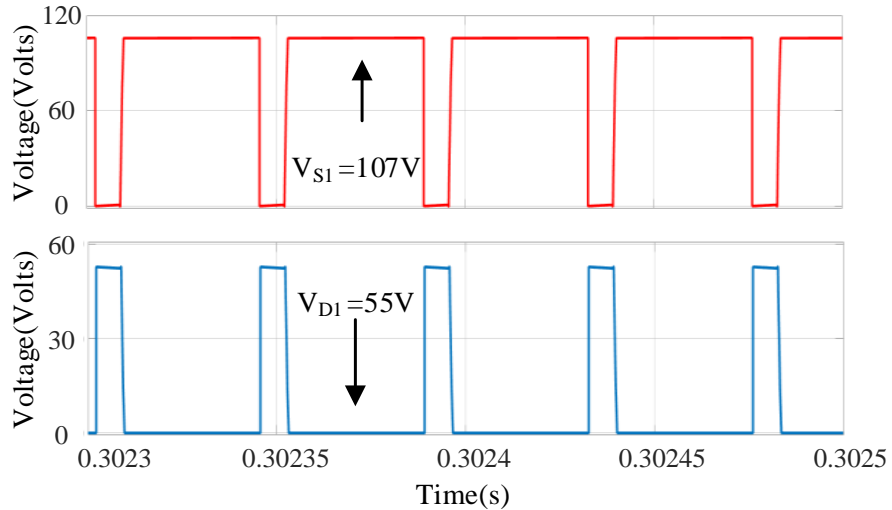

(b)
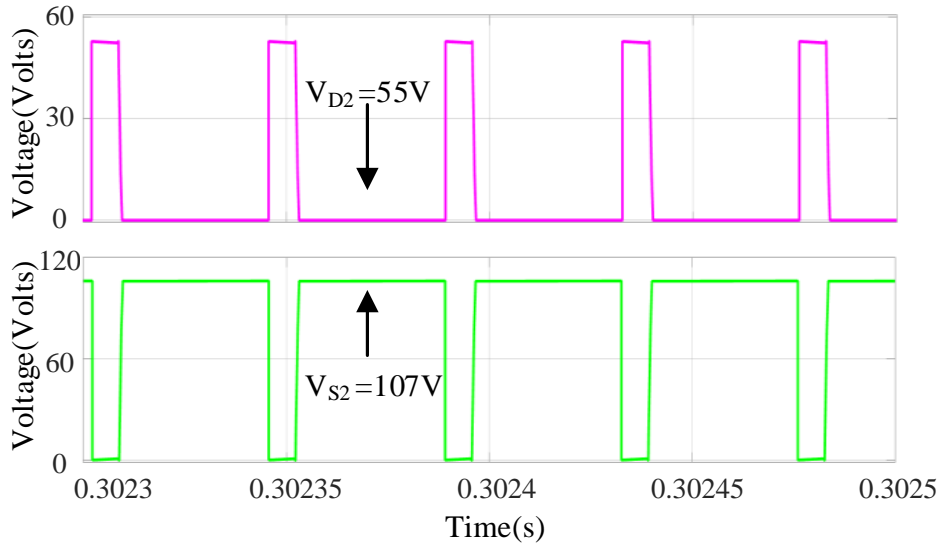

(c)

Figure 16. (a) Inductor current $I_{L},(\mathbf{b})$ voltage across $D_{1}$ and $S_{1}$, and (c) voltage across $D_{2}$ and $S_{2}$.

\section{Experimental Results}

In order to verify the feasibility of the proposed HS-SZC, a prototype is developed and tested in the laboratory. The circuit design and the complete experimental setup are shown in Figure 17. Moreover, the experimental parameters and specifications of devices are presented in Tables 4 and 5.

Table 5. Specification of experimental devices.

\begin{tabular}{cc}
\hline Device & Specification \\
\hline Inductors & $380 \mu \mathrm{H} / 10 \mathrm{~A}$ \\
Capacitors & $330 \mu \mathrm{F} / 100 \mathrm{~V}$ \\
Diode & MIC 10a10 \\
MOSFET & IRF540 \\
Signal generator & NE555P \\
MOSFET driver IC & IR2117 \\
\hline
\end{tabular}




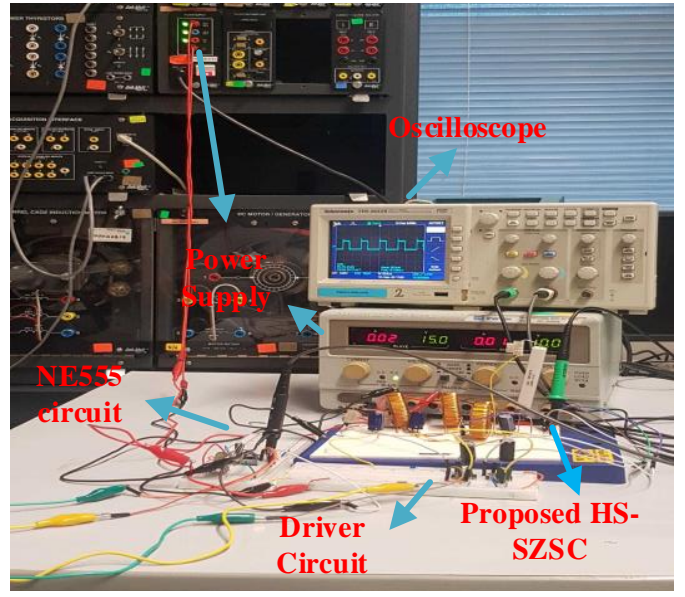

(a)

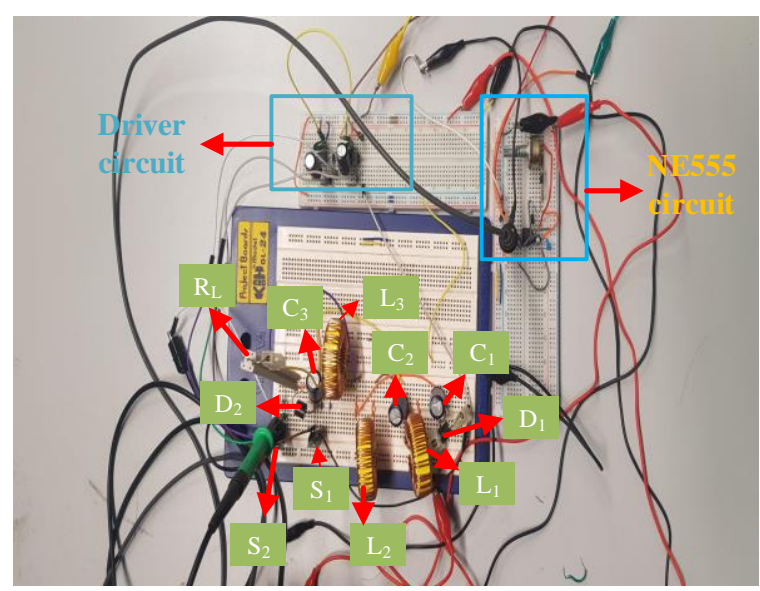

(b)

Figure 17. (a) Complete experimental setup and (b) circuit design of proposed HS-SZC.

The gate pulses for both MOSFETs $\left(S_{1}\right.$ and $\left.S_{2}\right)$ are generated using a NE555 timer IC with the proper switching frequency and duty cycle. The gate pulses for both switches are shown in Figure 18a, from which it can be observed that the gate signals ( $V_{G S 1}$ and $V_{G S 2}$ ) are operating at the frequency and duty cycle of $f_{S}=20 \mathrm{kHz}$ and $D=0.15$, respectively. The theoretical value of the output voltage of the proposed converter at a specified duty cycle and input voltage $\left(D=0.15, V_{I}=25 \mathrm{~V}\right)$ is $V_{O}=109 \mathrm{~V}$, for which the gain factor is calculated as 4.36. Correspondingly, the experimental value of the output voltage shown in Figure $18 \mathrm{~b}$ is $103 \mathrm{~V}$, for which the gain factor becomes 4.12. However, there is a discrepancy of $6 \mathrm{~V}$ when compared to the theoretical value. This is in accordance with the graph shown in Figure 8. Thus, the experimental results match well with the theoretical analysis.

The voltage stress waveforms for diodes $\left(D_{1}\right.$ and $\left.D_{2}\right)$ and switches $\left(S_{1}\right.$ and $\left.S_{2}\right)$ are presented in Figure $18 \mathrm{c}, \mathrm{d}$, respectively. It is worth noting that the switches $\left(S_{1}\right.$ and $\left.S_{2}\right)$ have a peak value of $103 \mathrm{~V}$ which is equivalent to the output voltage; thus, the proposed converter carries the features of the traditional converter. However, the diodes $\left(D_{1}\right.$ and $D_{2}$ ) have a reduced voltage stress of $51 \mathrm{~V}$, which is much lower than the output voltage. This is one of the key benefits of the proposed converter. The experimental waveforms for voltages across the capacitors $\left(C_{1}\right.$ and $\left.C_{2}\right)$ are shown in Figure $18 \mathrm{e}$ and the inductor currents along with the output current waveforms are shown in Figure 18f. Based on Equation (13), the theoretical value of the voltage across both capacitors $\left(C_{1}\right.$ and $\left.C_{2}\right)$ is $84 \mathrm{~V}$, respectively. However, the experimental value of the voltage across both capacitors is $80 \mathrm{~V}$. Therefore, the theoretical analysis is in good agreement with experimental results, which further validates the performance of the proposed converter.

Figure 19 describes the distribution of losses among all the components, i.e., inductor, capacitor, switch, diode, etc. From Figure 19, it can be derived that the diode contains the highest losses, which is $67.53 \%$ of the total power loss. However, the losses due to inductors, capacitors, and switches are $13.82 \%, 2.66 \%$, and $15.98 \%$, respectively. The sensitivity of the output power with respect to the duty cycle is shown in Figure 20. It can be noticed that a small change in the duty cycle causes a large variation on the output voltage and thus on the output power. This can be further verified by considering the value of the duty cycle from 0.20 to 0.25 in Figure 20. The output power at $D=0.20$ is approximately $80 \mathrm{~W}$; however, at $D=0.25$, the output power increased drastically to $175 \mathrm{~W}$. Apart from this, Figure 21 presents the experimental efficiency of the proposed circuit at different duty cycles. It is observable that the maximum efficiency of the proposed HS-SZC at a specified duty cycle $(D=0.15)$ is greater than $92 \%$. Figure 22 shows the sensitivity of the output voltage with variations in the duty cycle. Here, the output voltage is presented for ideal, simulated, and real conditions. The parasitic parameters are considered for the simulated output voltage. From Figure 22, it can be noticed that the ideal value of the output voltage for $D=0.15$ is $109 \mathrm{~V}$, while it is $107 \mathrm{~V}$ and $103 \mathrm{~V}$ for simulation and experimental conditions, 
respectively. This shows that ideal values calculated based on the theory comply with simulation and experimental results while showing a slight difference in the output voltage due to the presence of parasitic parameters. Hence, the optimization of these parasitic parameters will enhance the efficiency of the proposed design.

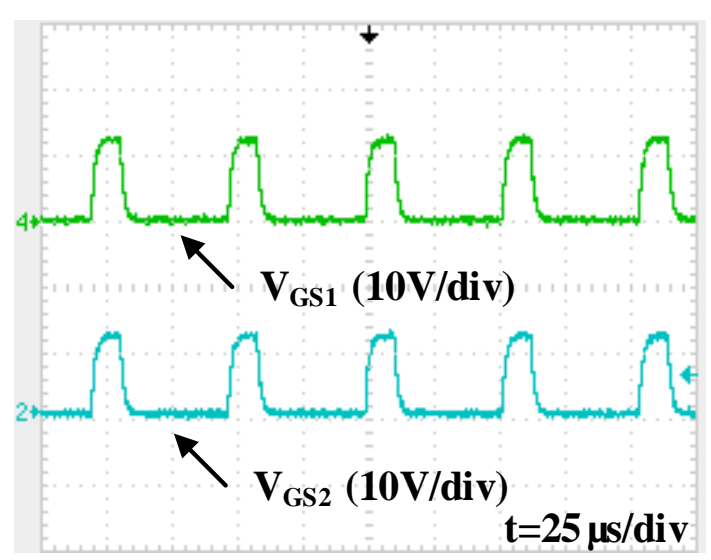

(a)

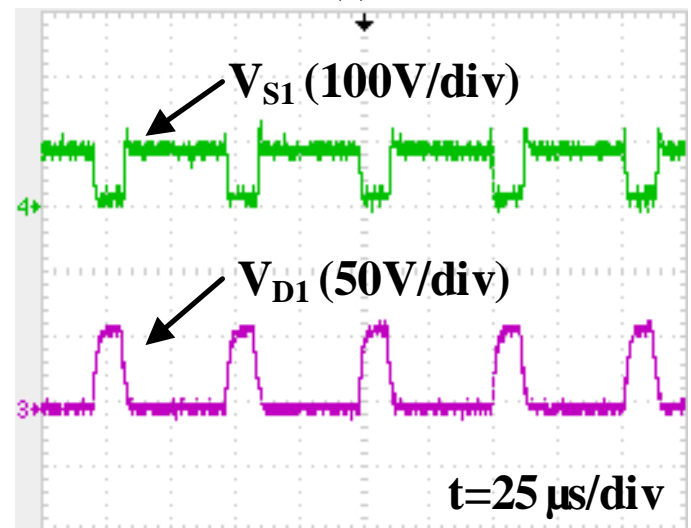

(c)

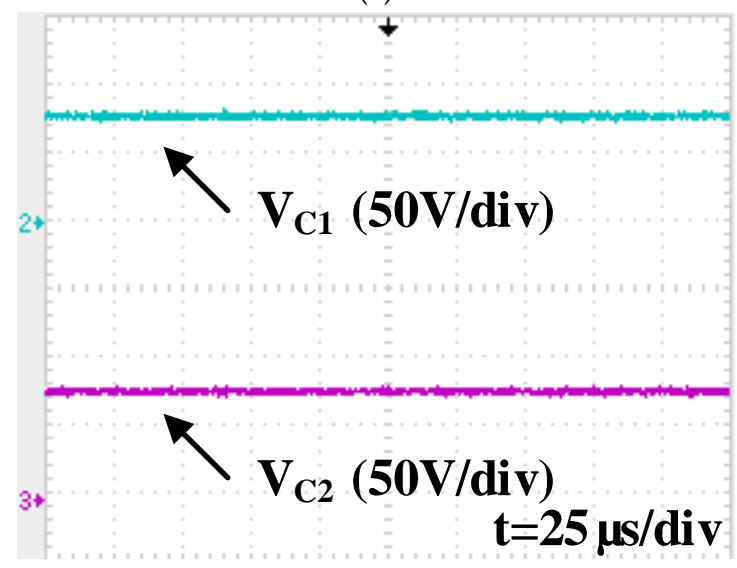

(e)

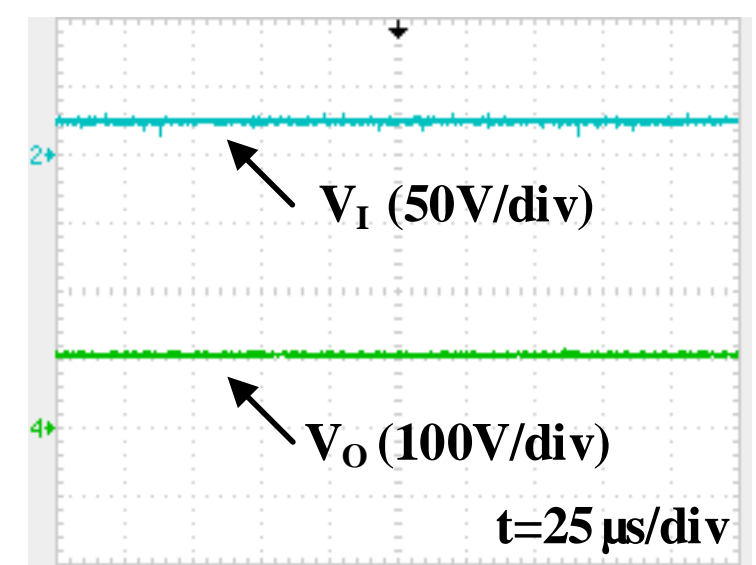

(b)

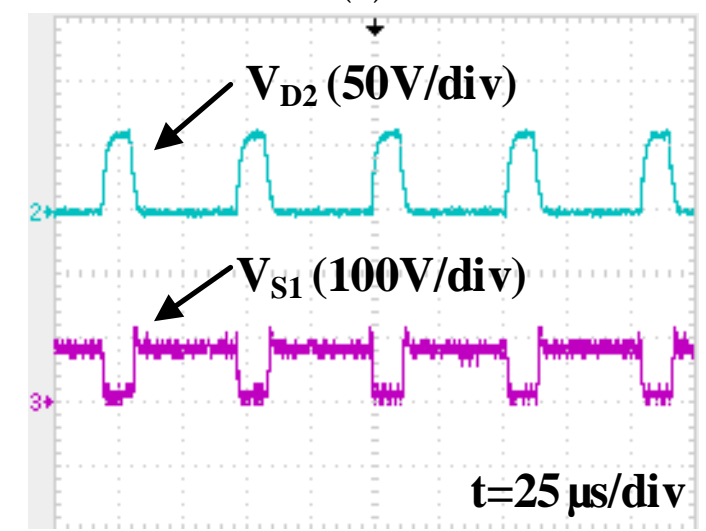

(d)

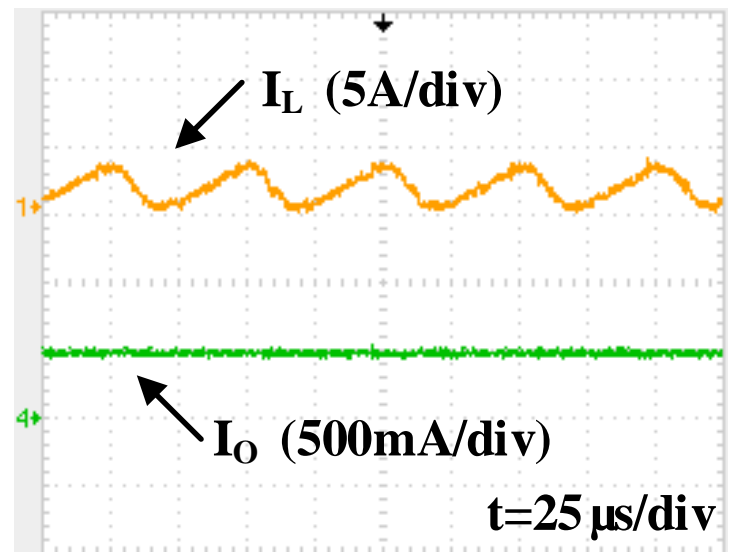

(f)

Figure 18. (a) Gate signals for both MOSFETs $S_{1}$ and $S_{2}$, (b) input and output voltages, (c) voltages across switch $S_{1}$ and diode $D_{1},(\mathbf{d})$ voltages across switch $S_{2}$ and diode $D_{2},(\mathbf{e})$ voltages across both capacitors $C_{1}$ and $C_{2}$, and (f) inductor current and output current. 
Diode loss

Switch Loss

Capacitor Loss

Inductor Loss

$15.98 \%$

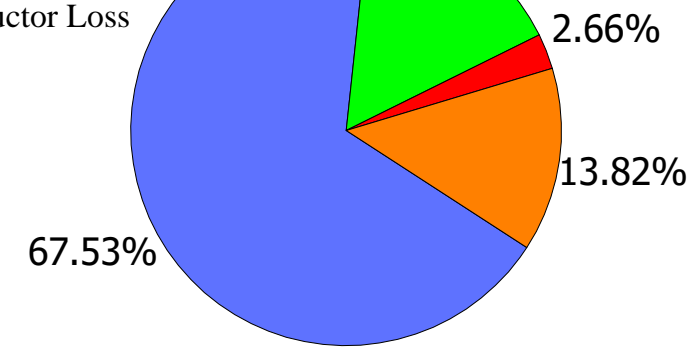

Figure 19. Total power loss distribution at the duty cycle of 0.15 .

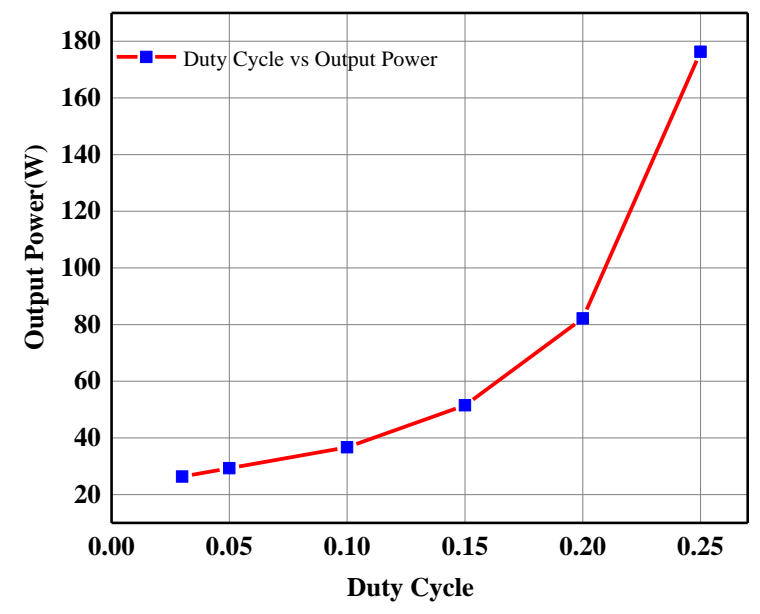

Figure 20. Variation of the output power at different duty cycles.

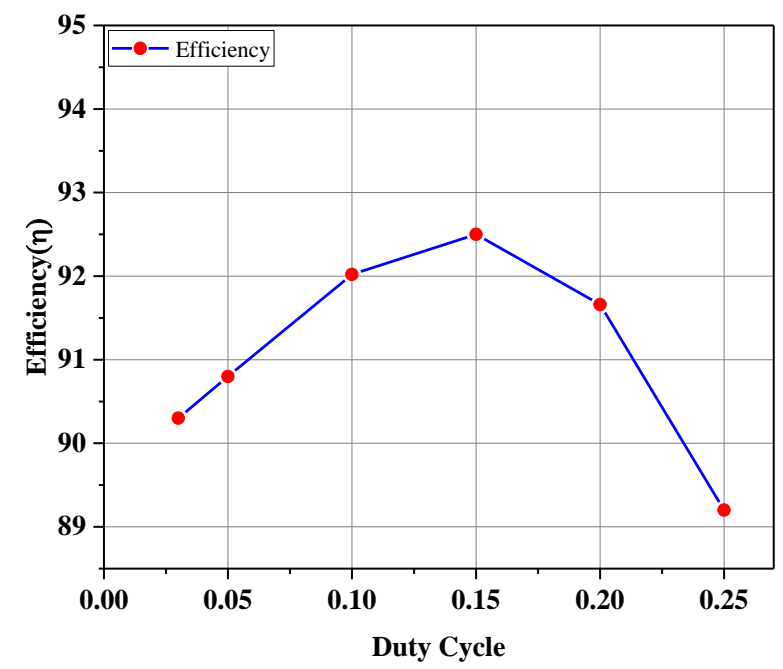

Figure 21. Experimental efficiency vs. duty cycle graph. 


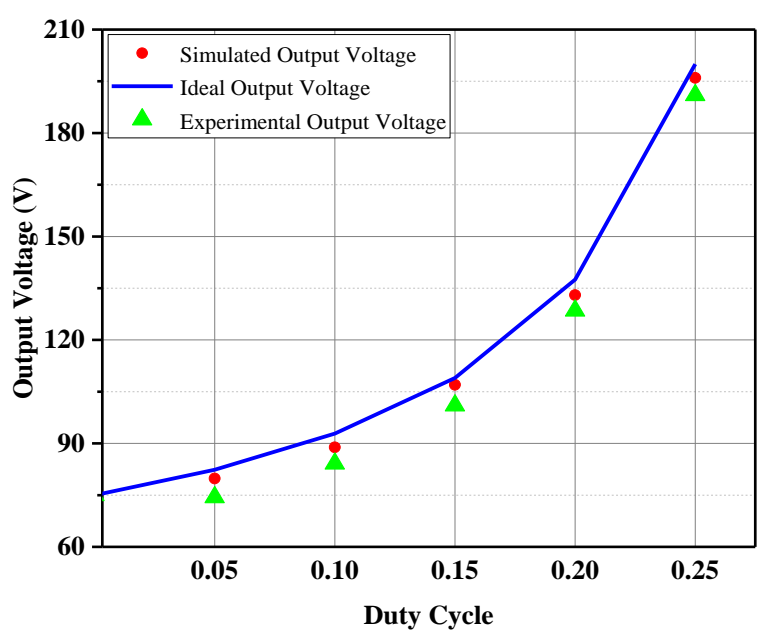

Figure 22. Ideal output voltage against the simulated output voltage with parasitic parameters and the experimental output voltage at different duty cycles.

\section{Conclusions and Future Research}

An advanced and efficient model of the switched Z-source DC-DC converter (HS-SZC) is presented in this study. The model is proposed using one inductor and switch at the backend of the conventional model of Z-source DC-DC converter and the derived voltage gain, i.e., $(3-4 D) /(1-3 D)$ clearly specifies the significant improvement in the boost ability of the newly designed Z-source DC-DC converter. The theoretical voltage gain of 4.36 at $D=0.15$ is achieved, while the simulation and experimental gains are recorded as 4.28 and 4.21 , respectively. The proposed design obtains a higher gain at a very small duty cycle, i.e., $D \leq 0.33$; thus, it eliminates the problems of the circuit complexity and larger duty cycle. Moreover, compared to the conventional Z-network converters, it utilizes a lower part count, which simultaneously reduces the cost and enhances the conversion efficiency. The proposed switched converter has a wide range of load capacity and voltage gains, which makes it suitable for applications with RESs. Finally, simulation and experimental results clearly justify the theoretical findings associated with the proposed converter. Future research will deal with the employment of the proposed topology with real applications, i.e., inverter, PV panel, etc.

Author Contributions: Conceptualization, R.K. (Rahul Kumar) and R.K. (Ramani Kannan); methodology, R.K. (Rahul Kumar) and A.M.; formal analysis, N.B.M.N. and A.M.; investigation, N.B.M.N. and R.K. (Rahul Kumar); writing — original draft preparation, R.K. (Rahul Kumar) and A.M.; writingreview \& editing, A.M. and R.K. (Ramani Kannan). All authors have read and agreed to the published version of the manuscript.

Funding: This research was supported by [Yayasan UTP Fundamental Research] under the grant number [Y-UTP 015LC0-069]. And the APC was funded by [Yayasan UTP Fundamental Research].

Data Availability Statement: No new data were created or analyzed in this study. Data sharing is not applicable to this article.

Acknowledgments: The authors would wish to acknowledge Universiti Teknologi PETRONAS (UTP) for providing all necessary facilities to support this research.

Conflicts of Interest: The authors declare no conflict of interest.

\section{References}

1. Gira, N.; Dahiya, A.K. Solar PV-BES in distribution system with novel technique for DC voltage regulation. Eng. Sci. Technol. Int. J. 2020, 23, 1058-1067. [CrossRef]

2. Ahmed, T.A.; Mohamed, E.E.; Youssef, A.-R.; Ibrahim, A.; Saeed, M.S.; Ali, A.I. Three phase modular multilevel inverter-based multi-terminal asymmetrical DC inputs for renewable energy applications. Eng. Sci. Technol. Int. J. 2020, 23, 831-839. [CrossRef] 
3. Chen, Y.; Member, S.; Huang, A.Q.; Yu, X.; Member, S. A High Step-Up Three-Port DC—DC Converter for Stand-Alone PV/Battery Power Systems. IEEE Trans. Power Electron. 2013, 28, 5049-5062. [CrossRef]

4. Gu, B.; Dominic, J.; Lai, J.-S.; Zhao, Z.; Liu, C. High Boost Ratio Hybrid Transformer DC—DC Converter for Photovoltaic Module Applications. IEEE Trans. Power Electron. 2012, 28, 2048-2058. [CrossRef]

5. Zubieta, L.E.; Lehn, P.W. A High Efficiency Unidirectional DC/DC Converter for Integrating Distributed Resources into DC Microgrids. In Proceedings of the IEEE First International Conference on DC Microgrids (ICDCM), Atlanta, GA, USA, 7-10 June 2015; pp. 280-284.

6. Syam, M.S.; Kailas, T.S. Grid connected PV system using Cuk converter. In Proceedings of the 2013 Annual International Conference on Emerging Research Areas and 2013 International Conference on Microelectronics, Communications and Renewable Energy, Kanjirapally, India, 4-6 June 2013. [CrossRef]

7. Sener, E.; Ertasgin, G. A 3-ph Grid-Connected Photovoltaic Inverter Utilizing Super-Lift Luo Converter. In Proceedings of the 2018 2nd International Symposium on Multidisciplinary Studies and Innovative Technologies (ISMSIT), Ankara, Turkey, 19-21 October 2018; pp. 1-5. [CrossRef]

8. Saravanan, S.; Babu, N.R. Analysis and implementation of high step-up DC-DC converter for PV based grid application. Appl. Energy 2017, 190, 64-72. [CrossRef]

9. Padmanaban, S.; Kabalci, E.; Iqbal, A.; Abu-Rub, H.; Ojo, O. Control strategy and hardware implementation for DC-DC boost power circuit based on proportional-integral compensator for high voltage application. Eng. Sci. Technol. Int. J. 2015, 18, 163-170. [CrossRef]

10. Shahir, F.M.; Babaei, E.; Farsadi, M. Voltage-Lift Technique Based Nonisolated Boost DC-DC Converter: Analysis and Design. IEEE Trans. Power Electron. 2017, 33, 5917-5926. [CrossRef]

11. Hu, X.; Gong, C. A High Gain Input-Parallel Output-Series DC/DC Converter with Dual Coupled Inductors. IEEE Trans. Power Electron. 2015, 30, 1306-1317. [CrossRef]

12. Salehi, S.; Zahedi, N.; Kheirollahi, R.; Babaei, E. Ultra High Step-up DC-DC Converter Based on Switched Inductor-Capacitor Cells. In Proceedings of the 2019 10th International Power Electronics, Drive Systems and Technologies Conference (PEDSTC), Shiraz, Iran, 12-14 February 2019; pp. 367-372. [CrossRef]

13. Tang, Y.; Fu, D.; Wang, T.; Xu, Z. Hybrid Switched-Inductor Converters for High Step-Up Conversion. IEEE Trans. Ind. Electron. 2015, 62, 1480-1490. [CrossRef]

14. Prudente, M.; Pfitscher, L.L.; Emmendoerfer, G.; Romaneli, E.F.; Gules, R. Voltage Multiplier Cells Applied to Non-Isolated DC-DC Converters. IEEE Trans. Power Electron. 2008, 23, 871-887. [CrossRef]

15. Fang, X. A novel Z-source dc-dc converter. In Proceedings of the 2008 IEEE International Conference on Industrial Technology, Chengdu, China, 21-24 April 2008; pp. 8-11. [CrossRef]

16. Galigekere, V.P.; Kazimierczuk, M.K. Analysis of PWM Z-Source DC-DC Converter in CCM for Steady State. IEEE Trans. Circuits Syst. I Regul. Pap. 2012, 59, 854-863. [CrossRef]

17. Takiguchi, T.; Koizumi, H. Quasi-Z-source dc-dc converter with voltage-lift technique. In Proceedings of the IECON 2013 - 39th Annual Conference of the IEEE Industrial Electronics Society, Vienna, Austria, 10-13 November 2013; pp. 1191-1196. [CrossRef]

18. Yang, L. A Quasi-Z -Source DC-DC Converter. In Proceedings of the 2014 IEEE Energy Conversion Congress and Exposition (ECCE), Pittsburgh, PA, USA, 14-18 September 2014. [CrossRef]

19. Qiaojie, Z.; Yunxia, L.; Qiao, Y. Quasi-Z-source DC/DC converter based on switched inductor-capacitor unit and passivity based controller. In Proceedings of the 8th Renewable Power Generation Conference (RPG 2019), Shanghai, China, 24-25 October 2019; pp. 1-7. [CrossRef]

20. Evran, F.; Aydemir, M.T. Z-source-based isolated high step-up converter. IET Power Electron. 2013, 6, 117-124. [CrossRef]

21. Sharifi, S.; Monfared, M. Modified Series and Tapped Switched-Coupled-Inductors Quasi-Z-Source Networks. IEEE Trans. Ind. Electron. 2019, 66, 5970-5978. [CrossRef]

22. Poorali, B.; Torkan, A.; Adib, E. High step-up Z-source DC-DC converter with coupled inductors and switched capacitor cell. IET Power Electron. 2015, 8, 1394-1402. [CrossRef]

23. Zhang, G.; Zhang, B.; Li, Z.; Qiu, D.; Yang, L.; Halang, W.A. A 3-Z-Network Boost Converter. IEEE Trans. Ind. Electron. 2015, 62, 278-288. [CrossRef]

24. Torkan, A.; Ehsani, M. A Novel Nonisolated Z-Source DC-DC Converter for Photovoltaic Applications. IEEE Trans. Ind. Appl. 2018, 54, 4574-4583. [CrossRef]

25. Krishna, M.V.; Varma, L.T.V.; Kumar, M.A. Simulation of High Step up Z-Source DC-DC Converter with Voltage Multiplier Using Coupled Inductors. IJRAR Int. J. Res. Anal. Rev. 2018, 5, 594-598.

26. Haji-Esmaeili, M.M.; Babaei, E.; Sabahi, M. High Step-Up Quasi-Z Source DC-DC Converter. IEEE Trans. Power Electron. 2018, 33, 10563-10571. [CrossRef]

27. Zhang, G.; Iu, H.H.-C.; Zhang, B.; Li, Z.; Fernando, T.; Chen, S.-Z.; Zhang, Y. An Impedance Network Boost Converter with a High-Voltage Gain. IEEE Trans. Power Electron. 2017, 32, 6661-6665. [CrossRef]

28. Shen, H.; Zhang, B.; Qiu, D. Hybrid Z-Source Boost DC-DC Converters. IEEE Trans. Ind. Electron. 2017, 64, 310-319. [CrossRef]

29. Vaz, A.R.; Tofoli, F.L. Detailed design procedure of a DC-DC buck-boost converter employing a passive snubber. In Proceedings of the 2017 Brazilian Power Electronics Conference (COBEP), Juiz de Fora, Brazil, 19-22 November 2017; pp. 1-6. [CrossRef] 
30. H. P. International R. Mosfet. IRFP4768PbF. p. PD-97379. Available online: https:/ /www.infineon.com/dgdl/irfp4768pbf.pdf? fileId $=5546 \mathrm{~d} 462533600 a 40153562$ c959b2021 (accessed on 12 December 2016).

31. Zeng, J.; Wu, J.; Liu, J.; Guo, H. A Quasi-Resonant Switched-Capacitor Multilevel Inverter with Self-Voltage Balancing for Single-Phase High-Frequency AC Microgrids. IEEE Trans. Ind. Inform. 2017, 13, 2669-2679. [CrossRef]

32. Yang, L.; Qiu, D.; Zhang, B.; Zhang, G.; Xiao, W. A modified Z-source DC-DC converter. In Proceedings of the 2014 16th European Conference on Power Electronics and Applications, Lappeenranta, Finland, 26-28 August 2014. [CrossRef]

33. Zhang, Y.; Liu, Q.; Gao, Y.; Li, J.; Sumner, M. Hybrid Switched-Capacitor/Switched-Quasi-Z-Source Bidirectional DC-DC Converter with a Wide Voltage Gain Range for Hybrid Energy Sources EVs. IEEE Trans. Ind. Electron. 2019, 66, 2680-2690. [CrossRef]

34. Quasi-z-source, S.H.S.; Converter, D.C.D.C. Soft-Switched High Step-Up Quasi-Z-Source DC-DC Converter. IEEE Trans. Ind. Electron. 2020, 67, 4547-4555.

35. Maalandish, M.; Hosseini, S.H.; Ghasemzadeh, S.; Babaei, E.; Jalilzadeh, T. A Novel Multiphase High Step-Up DC/DC Boost Converter with Lower Losses on Semiconductors. IEEE J. Emerg. Sel. Top. Power Electron. 2019, 7, 541-554. [CrossRef]

36. Wu, G.; Ruan, X.; Ye, Z. Nonisolated High Step-Up DC-DC Converters. IEEE Trans. Ind. Electron. 2015, 62, 383-393. [CrossRef]

37. Chen, M.; Li, K.; Hu, J.; Ioinovici, A. Generation of a Family of Very High DC Gain Power Electronics Circuits Based on Switched-Capacitor-Inductor Cells Starting from a Simple Graph. IEEE Trans. Circuits Syst. I Regul. Pap. 2016, 63, $2381-2392$. [CrossRef] 